\title{
TGF- $\beta$ Signaling, Activated Stromal Fibroblasts, and Cysteine Cathepsins B and L Drive the Invasive Growth of Human Melanoma Cells
}

\author{
Miao Yin, ${ }^{*}$ Johanna Soikkeli, ${ }^{,}$Tiina Jahkola, ${ }^{\dagger}$ \\ Susanna Virolainen, ${ }^{*}$ Olli Saksela, ${ }^{\ddagger}$ and \\ Erkki Hölttä* \\ From the Department of Pathology,* Haartman Institute, \\ University of Helsinki and Helsinki University Central Hospital, \\ and the Departments of Plastic Surgery ${ }^{\dagger}$ and Dermatology, ${ }^{\ddagger}$ \\ Helsinki University Central Hospital, Helsinki, Finland
}

Accumulating evidence indicates that interactions between cancer cells and stromal cells are important for the development/progression of many cancers. Herein, we found that the invasive growth of melanoma cells in three-dimensional-Matrigel/collagen-I matrices is dramatically increased on their co-culture with embryonic or adult skin fibroblasts. Studies with fluorescent-labeled cells revealed that the melanoma cells first activate the fibroblasts, which then take the lead in invasion. To identify the physiologically relevant invasion-related proteases involved, we performed genome-wide microarray analyses of invasive human melanomas and benign nevi; we found up-regulation of cysteine cathepsins $B$ and $L$, matrix metalloproteinase (MMP)-1 and -9, and urokinase- and tissue-type plasminogen activators. The mRNA levels of cathepsins $\mathrm{B} / \mathrm{L}$ and plasminogen activators, but not MMPs, correlated with metastasis. The invasiveness/growth of the melanoma cells with fibroblasts was inhibited by cell membrane-permeable inhibitors of cathepsins $B / L$, but not by wide-spectrum inhibitors of MMPs. The IHC analysis of primary melanomas and benign nevi revealed cathepsin $B$ to be predominantly expressed by melanoma cells and cathepsin $L$ to be predominantly expressed by the tumor-associated fibroblasts surrounding the invading melanoma cells. Finally, cathepsin B regulated TGF- $\beta$ production/signaling, which was required for the activation of fibroblasts and their promotion of the invasive growth of melanoma cells. These data provide a basis for testing inhibitors of TGF- $\beta$ signaling and cathepsins $B / L$ in the therapy of invasive/metastatic melanomas. (Am J Pathol 2012, 181:2202-2216; http://dx. doi.org/10.1016/j.ajpath.2012.08.027)

Tumors must be viewed as complex tissues and not as composed of cancer cells alone. Indeed, in the local microenvironment, cancer cells extensively interact with various stromal components, consisting of extracellular matrix (ECM) proteins/polysaccharides and several kinds of cells, such as endothelial cells, inflammatory cells, and fibroblasts, which reciprocally regulate each other. ${ }^{1-4}$ Several studies have suggested a key role for tumor/ cancer-associated fibroblasts (CAFs) in tumor development and progression. ${ }^{5-7}$ However, the precise molecular mechanisms of the interplay between the CAFs and cancer cells still remain largely elusive.

Human cutaneous melanoma offers a good target for studying the factors involved in tumor progression, ${ }^{8}$ because specimens from different stages of its progression can be relatively easily obtained for analysis. Furthermore, melanoma is one of the most aggressive malignancies, with a high mortality rate for patients with advanced disease; indeed, the survival of patients with metastatic melanoma has not improved much during the past 30 years. $^{9}$ During the past few years, however, we have learned much about the molecular and genetic alterations associated with melanoma development and progression, ${ }^{10-12}$ and new promising drugs, such as the mutant (V600E) BRAF kinase inhibitor ${ }^{13}$ for selected melanoma cases, are emerging. Molecularly targeted cancer therapies for solid tumors (targeted against the tumor

Supported by the Academy of Finland, Finnish Cancer Organizations, Helsinki University Central Hospital Research Funds (Departments of Dermatology and HUSLAB), and the Helsinki Graduate Program in Biotechnology and Molecular Biology.

Accepted for publication August 23, 2012.

Supplemental material for this article can be found at http://ajp. amjpathol.org or at $h$ ttp://dx.doi.org/10.1016/j.ajpath.2012.08.027.

Address reprint requests to Erkki Hölttä, M.D., Ph.D., Department of Pathology, Haartman Institute, University of Helsinki, PO Box 21 (Haartmaninkatu 3), Fl-00014 Helsinki, Finland. E-mail: erkki.holtta@helsinki.fi. 
cells) have, however, usually failed in long-term clinical trials because of the development of drug resistance. With the current awareness of the importance of the tumor microenvironment in tumor progression, it is reasonable to expect that studies elucidating the interplay between the melanoma cells and stromal components could reveal new effective targets for therapy.

The acquisition of invasive potential by tumor cells is a key prerequisite step for metastasis. In invasion/metastasis, proteolytic degradation/processing of the basement membrane/ECM and signaling components is needed. This is a complex process, thought to involve several proteases from five different catalytic classes (ie, serine, threonine, aspartic, cysteine, and metalloproteases). In previous studies, most attention has been paid to matrix metalloproteases (MMPs) and the urokinase-type plasminogen activator (UPA $)^{14-17}$ and less attention has been paid to cathepsins ${ }^{17-20}$; most studies have been performed in two-dimensional-cell culture or animal models and examined only cancer cellspecific proteases.

In this study, we aimed at identifying the invasionrelated proteases in melanomas relevant for the development and progression of the human disease. First, we used three-dimensional (3D)-Matrigel/collagen-I matrices, mimicking the tumor microenvironment, to study the interplay between human melanoma cells (harboring BRAF or NRAS mutations) and skin fibroblasts in the invasive growth. We further performed genome-wide gene expression analyses of primary melanomas and benign nevi to identify the physiologically relevant proteases involved in invasion/metastasis, and used specific protease inhibitors to assess their potential functional significance. In addition, we analyzed by immunohistochemistry $(\mathrm{IHC})$ the cellular expression patterns of the key proteases identified, cathepsins $B$ and $L$, in the tumor tissues. Finally, we studied the potential role of cathepsin $\mathrm{B}$ in the processing of transforming growth factor (TGF)- $\beta$ and the significance of the TGF- $\beta$ signaling in the invasion process.

\section{Materials and Methods}

\section{Reagents}

Purified cathepsin $L$ from human liver (specific activity, $6.036 \mathrm{U} / \mathrm{mg}$ protein), purified cathepsin B from human liver (specific activity, $32.7 \mathrm{U} / \mathrm{mg}$ protein), the wide-spectrum MMP inhibitors GM6001 (Ilomastat and its negative control), BB-2516 (Marimastat), cathepsin L inhibitors I and II, and cathepsin B inhibitors CA-074 and CA-O74Me (a cell membrane-permeable analogue of CA-074) were obtained from Merck/Calbiochem (Darmstadt, Germany). The MMP inhibitor BB-3103 (inhibitory concentration of $50 \%, 2 \mathrm{nmol} / \mathrm{L}$ for MMP-1, $10 \mathrm{nmol} / \mathrm{L}$ for MMP-2, 30 nmol/L for MMP-3, $20 \mathrm{nmol} / \mathrm{L}$ for MMP-7, $7 \mathrm{nmol} / \mathrm{L}$ for MMP-9, and $4 \mathrm{nmol} / \mathrm{L}$ for MMP-13) was obtained from British Biotech Pharmaceuticals Ltd (Oxford, UK), the TGF- $\beta$ receptor I (ALK5) inhibitor SB-505124 was obtained from Sigma-Aldrich (St Louis, MO), the neutralizing antibodies to TGF- $\beta$ (monoclonal anti-TGF- $\beta 1$, anti-TGF$\beta 2$, and anti-TGF- $\beta 3$ antibody) was obtained from R\&D Systems (Minneapolis, MN), UPA inhibitor was obtained from American Diagnostica Inc. (Stamford, CT), and recombinant human TGF- $\beta 1$ was obtained from Humanzyme (Chicago, IL). Fibroblast medium-serum free was obtained from ScienCell Research Laboratories (Carlsbad, CA), growth factor-reduced Matrigel and rat tail collagen type I, high concentration, were obtained from Becton Dickinson Biosciences (Bedford, MA), and Celltracker Green CMFDA and Celltracker Red CMTPX were obtained from Invitrogen-Molecular Probes, Inc. (Eugene, OR).

\section{Cell Culture}

The nonmetastatic (or poorly metastatic) human vertical growth phase (VGP) melanoma cell lines WM115 (BRAFV600D mutation; obtained from ATCC-LGC Standards, Borås, Sweden) and WM793 (BRAFV600E; provided by Dr. Meenhard Herlyn, Wistar Institute, Philadelphia, PA), ${ }^{21}$ the metastatic melanoma cell lines SKMEL-28 (BRAFV600E; obtained from ATCC-LGC Standards), SK-MEL-103 (NRASQ61R), and SK-MEL-147 (NRASQ61R) (both originating from Dr. Alan Houghton, Memorial Sloan-Kettering Cancer Center, New York, NY) ${ }^{22,23}$; provided by Dr. Maria Soengas, Spanish National Cancer Research Center, Madrid, Spain), and WM239 (BRAFV600D; obtained from Dr. M. Herlyn), ${ }^{21}$ the embryonic skin fibroblasts (HES), and adult skin fibroblasts (HAS) ${ }^{24}$ were grown in RPMI 1640 medium supplemented with $10 \%$ fetal bovine serum (Invitrogen, Carlsbad, CA) and antibiotics (penicillin and streptomycin) at $37^{\circ} \mathrm{C}$ in a $5 \% \mathrm{CO}_{2}$ atmosphere.

\section{Labeling Living Cells with Fluorescent Celltracker Dyes}

Cells in exponential growth were washed twice with serum-free RPMI 1640 medium, incubated in prewarmed medium containing Celltracker Green CMFDA or Celltracker Red CMTPX (5 or $10 \mu \mathrm{mol} / \mathrm{L}$, respectively; Invitrogen-Molecular Probes, Inc.) at $37^{\circ} \mathrm{C}$ in a $5 \% \mathrm{CO}_{2}$ atmosphere for 45 minutes. After that, the medium was replenished with normal growth medium, and the cells were grown overnight before use in the experiments.

\section{Invasion Assays}

The invasive/aggressive behavior of the cells was studied using 3D-Matrigel invasion/outgrowth assays, essentially as previously described ${ }^{25}$ Briefly, 1 to $2 \times 10^{4}$ melanoma cells and fibroblasts (HES or HAS) alone and $10^{4}$ melanoma cells mixed with $10^{4} \mathrm{HES}$ or HAS cells in the coculture assays were seeded onto 24-well plates precoated with $300 \mu \mathrm{L}$ of Matrigel (diluted 1:3 in RPMI 1640 medium), and allowed to adhere for 1 hour at $37^{\circ} \mathrm{C}$. Then, a second 250- $\mu \mathrm{L}$ layer of Matrigel (1:3) was cast above the cells. Finally, $500 \mu \mathrm{L}$ of RPMI 1640 medium containing $10 \%$ fetal bovine serum was added on top of the 
Matrigel matrix. More important, we and other researchers have previously found that this thick, two-layer Matrigel assay (measuring the invasive, migratory, and proliferative ability of the cells) correlates better with the tumor cell invasiveness/aggressiveness in vivo than the Matrigel-coated filter/Boyden chamber assays. ${ }^{26,27}$ Corresponding invasion assays were also performed with cells embedded in a mixture of Matrigel $(2 \mathrm{mg} / \mathrm{mL})$ and collagen-I ( 2 or $4 \mathrm{mg} / \mathrm{mL}),{ }^{28,29}$ because collagen-l is the major matrix protein in dermis/connective tissues, acting as a barrier to cellular invasion. In testing the effects of various inhibitors, the experiments were performed with or without MMP inhibitors GM6001 (or its negative control), BB2516, or BB-3103 $(0.5,5,10$, and $15 \mu \mathrm{mol} / \mathrm{L})$, cathepsin B inhibitors CA-074 or CA-074Me (1, 2, and $5 \mu \mathrm{mol} / \mathrm{L})$, cathepsin $L$ inhibitors I and II $(0.5,5$, and $15 \mu \mathrm{mol} / \mathrm{L})$, TGF- $\beta$ receptor I (ALK5) inhibitor SB-505124 (1, 2.5, 5, and $10 \mu \mathrm{mol} / \mathrm{L}$ ), or the neutralizing antibodies to TGF- $\beta$ $(2.5,5$, and $10 \mu \mathrm{g} / \mathrm{mL})$, added into the Matrigel and the growth medium. The growth medium was replenished every third day. The growth pattern and morphological characteristics of the cells were documented daily by phase-contrast microscopy and photography using an Olympus CK2 microscope, equipped with phase-contrast optics and a digital camera, or an Olympus IX71 microscope and an Olympus DP70 camera (Tokyo, Japan).

\section{Western Blot Analysis of Proteins}

Whole cell extracts and secreted proteins in conditioned media were analyzed by using Western blot analysis, as previously described. ${ }^{27,30}$ Monoclonal antibodies to TGF- $\beta$ (R\&D Systems), polyclonal antibodies to human hepatocyte growth factor (HGF; R\&D Systems), monoclonal antibodies to cathepsin B (CB 59-4B11; Alexis/Enzo Life Sciences, Lausanne, Switzerland), and monoclonal antibodies to $\alpha$-smooth muscle actin ( $\alpha$-SMA; Dako, Glostrup, Denmark) were used to detect the respective proteins. Polyclonal antibodies to $\alpha$-tubulin (Rockland Immunochemicals, Gilbertsville, PA) and monoclonal antibodies to actin (EMD Millipore-Calbiochem, Darmstadt, Germany) were used as a loading control.

\section{Patient Samples}

Fresh benign nevi $(n=21)$ from healthy volunteers and primary melanoma specimens $[n=27$ : Breslow's thickness, $\leq 2.0 \mathrm{~mm}$ (median, $1.5 \mathrm{~mm}$; range, 0.6 to $2.0 \mathrm{~mm}$ ), $n=11$; and $>2.0 \mathrm{~mm}$ (median, $6.4 \mathrm{~mm}$; range, 2.4 to 27 $\mathrm{mm}$ ), $n=16$ ] (for microarray analyses) were obtained by surgical excision at Helsinki University Central Hospital, Helsinki, Finland. Adjacent sections were subjected to pathological and $\mathrm{IHC}$ examinations by an experienced dermatopathologist (S.V.). The protocols for taking the specimens were approved by the Ethics Committees of the Helsinki University Central Hospital. Furthermore, informed consent was obtained from all patients. Formalinfixed, paraffin-embedded nevi $(n=13)$ and primary melanomas $(n=60)$ (for $\mathrm{HC}$ analyses) were from the archives of the Department of Pathology, University of Helsinki, Helsinki.

\section{Microarray Analyses}

Microarray analyses with the Affymetrix Human Genome U133 Set and U133 Plus 2.0 arrays were performed according to the protocols of the manufacturer (Affymetrix Inc., Santa Clara, CA), as previously described. ${ }^{24,31}$ The data were processed by RMAExpress version 1.0.4 (http://rmaexpress.bmbolstad.com), and the probe sets were ordered both by significance analysis of microarrays $(\mathrm{SAM})^{32}$ and fold-change ranking, combined with $P$ value calculations, ${ }^{33}$ essentially as previously described. ${ }^{24}$

\section{RT-PCR Analyses}

Cathepsin $B$ and $L$ gene expression levels in melanoma cells and fibroblasts were detected by RT-PCR, which was performed essentially as previously described. ${ }^{31,34}$ Briefly, $1 \mu \mathrm{g}$ of total RNA extracted from the cells with the RNeasy kit (Qiagen, Crawley, UK) was reverse transcribed to cDNA. The primers (forward and reverse) designed for cathepsin B were as follows: 5'-AAGCTTCGATGCACGGGAACAATG-3' and 5'-TCCAGCCACCACTTCTGATTCGAT-3', respectively; cathepsin L, 5' -GTCAGTGTGGTTCTTGTTGG-3' and 5'-AAGGACTCATGACCTGCATC-3', respectively; and $\beta$-actin, 5'-GCTCGTCGTCGACAACGGCTC-3' and 5' - CAAACATGATCTGGGTCATCTTCTC-3', respectively. The PCRs, optimized to be in the linear range, consisted of denaturation $\left(94^{\circ} \mathrm{C}\right.$ for 2 minutes), followed by 20 to 25 cycles of denaturation at $94^{\circ} \mathrm{C}$ for 60 seconds, annealing at $56^{\circ} \mathrm{C}$ for 45 seconds, extension at $72^{\circ} \mathrm{C}$ for 90 seconds, and a final elongation of 7 minutes at $72^{\circ} \mathrm{C}$. The products were resolved in 2\% agarose gels, stained with GelStar nucleic acid gel stain (Cambrex Bio Science Rockland, Rockland, ME), and visualized under UV light. The gel runs were documented with Alpha Imager HP and Alpha EaseFC Software, version 5.01 (Alpha Innotech Corporation, San Leandro, CA).

\section{IHC Staining}

Immunostainings were performed essentially as previously described. ${ }^{35}$ We first tested the performance of several commercial antibodies to cathepsin B (data not shown), because of the known unsatisfactory function of many previously used ones (eg, polyclonal sheep antibodies) in IHC. ${ }^{36}$ Antibody staining conditions were then optimized. The slides were exposed to heat-induced epitope retrieval and incubated with the antibodies to cathepsin B (5 g/mL; CB 59-4B11) and cathepsin L (7 g/mL, ab7431; Abcam, Cambridge, UK).

\section{Statistical Analysis}

A two-tailed Welch's t-test was used for the significance analyses. $P<0.05$ was considered statistically signifi- 
cant. The Kaplan-Meier survival curves were analyzed with PASW Statistics 18 software (SPSS Inc., Chicago, $\mathrm{IL}$ ), using the log-rank (Mantel-Cox) test.

\section{Results}

\section{Reciprocal Interplay between Melanoma Cells and Skin Fibroblasts Promotes the Invasive Growth of Melanoma Cells}

We and other researchers have shown that fibroblasts contribute to melanoma progression/invasion in vitro ${ }^{37-39}$ and in vivo. ${ }^{24,35}$ To assess the importance of stromal fibroblasts for the invasive growth of melanoma cells, we first analyzed the growth patterns of VGP WM793 melanoma cells cultured alone or mixed in a 1:1 ratio with embryonic (HES) or adult (HAS) skin fibroblasts in 3DMatrigel and Matrigel/collagen-I matrices. The early VGPderived WM793 cells exhibited no or only poor invasion during the first 24 hours (Figure 1, A and D; see also Supplemental Figure S1A at http://ajp.amjpathol.org), but showed some invasive growth during prolonged culture (see Supplemental Figure S1B at http://ajp.amjpathol. org). The HES or HAS fibroblasts, in turn, were not able to grow or invade on their own in 3D-Matrigel, but remained as isolated, round to oval cells, and died during the prolonged culture (Figure 1, B and E; data not shown). Interestingly, when HES or HAS cells were admixed and co-cultured with WM793 cells, the fibroblasts became spindle shaped/activated, and assembled in direct contact with the melanoma cells. This interaction appeared to dramatically increase the invasive growth potential of both the fibroblasts and WM793 cells, resulting in a rapidly expanding network of invading cells (Figure 1, C and F).

A clear, but less intense, promotion of the invasive growth was also observed when WM793 cells were seeded in the middle of Matrigel and fibroblasts were seeded on top of Matrigel, so that the melanoma cells and fibroblasts could not contact each other directly when plated (Figure 1, G-L). After 24 hours of culture, small conglomerates of fibroblasts and melanoma cells in direct contact were nevertheless observed (Figure 1, I and L). Furthermore, we found HES and HAS cells seeded on top of Matrigel to become activated on addition of conditioned growth media (CM) from WM793 cells (see Supplemental Figure S2 at http://ajp.amjpathol.org). These data suggested that melanoma cells secrete some factor(s) that can activate even the quiescent adult skin fibroblasts at a distance and induce their migration to a physical contact with the melanoma cells. Reciprocally, we also found that the secreted factors/CM from HAS and particularly from HES increased the invasive activity of WM793 cells (see Supplemental Figure S3A at http:// ajp.amjpathol.org). Notably, the CM from HES appeared to induce in WM793 cells an epithelial-mesenchymal transition-like conversion in morphological characteristics (see Supplemental Figure S3A at http://ajp.amjpathol. org). The higher potency of the CM from HES than HAS was understandable, because the embryonic cells rep- resented activated fibroblasts, as evidenced by their expression of increased amounts of HGF and $\alpha$-SMA (ACTA2), markers of myofibroblasts (see Supplemental Figure S3B at $h$ ttp://ajp.amjpathol.org).

To better define the invasion patterns and mutual cellular interactions, we labeled WM793 cells and fibroblasts with different fluorescent CellTracker probes, CMTPX (red) and CMFDA (green), respectively. Although the cell tracing dyes might have some adverse effects, ${ }^{40}$ we did not find any appreciable changes in the behavior of the cells. However, the fluorescence images do not, of course, show the cell morphological characteristics as clearly as the phase-contrast microscopy. Nevertheless, images captured by fluorescent microscopy showed that when WM793 cells were co-cultured with HES (Figure 2, A-C; see also Supplemental Figure S4A at $h$ ttp://ajp.amjpathol. org) or HAS (Figure 2D; see also Supplemental Figure S4A at http://ajp.amjpathol.org), most of the melanoma
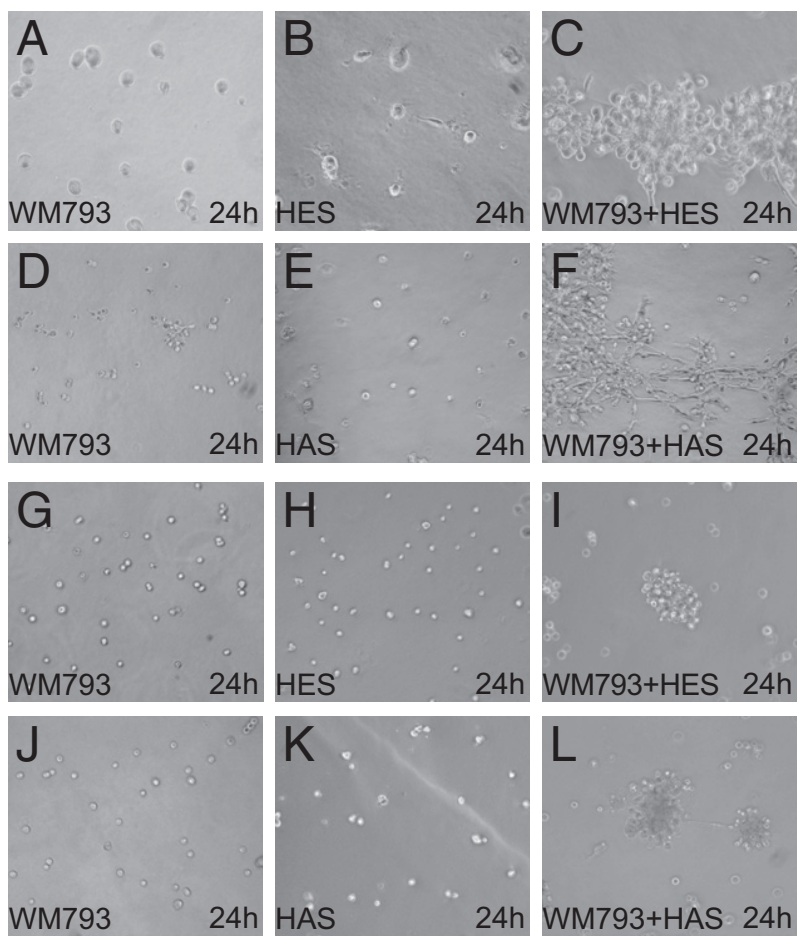

Figure 1. Growth patterns of human WM793 VGP melanoma cells and human embryonic and adult skin fibroblasts, HES and HAS, cultured alone or together, in direct or indirect contact, in 3D-Matrigel. A-C: Culture of WM793 (A) and HES (B) cells $\left(10^{4}\right.$ cells per well) alone and WM793 and HES cells $\left(\mathbf{C} ; 10^{4}+10^{4}\right.$ cells per well) together in the middle of Matrigel for 24 hours. Original magnification, $\times 200$. D-F: Culture of WM793 (D) and HAS (E) cells alone and WM793 and HAS cells together (F), as previously described. Original magnification, $\times 100$. G-I: Culture of WM793 cells alone in the middle of Matrigel (G), HES cells alone on top of Matrigel (H), and WM793 and HES cells together (I) for 24 hours, seeded in the middle and on top of Matrigel, respectively. Original magnification, $\times 100$. J-L: Culture of WM793 cells alone in the middle of Matrigel (J), HAS cells alone on top of Matrigel (K), and WM793 and HAS cells together $(\mathbf{L})$, as previously described. Original magnification, $\times 100$. The behavior of the cells was followed by light phase-contrast microscopy and documented by photography in more than three independent experiments, with similar results. The HES and HAS cells cultured alone do not spread or survive ( $<1 \%$ of the fibroblasts elongated) under any of these growth conditions but become elongated (spindle shaped)/activated on co-culture with WM793 cells, which then results in fibroblastmelanoma cell interaction/assembly and a fibroblast activation-dependent increase in the invasive growth of both cell types. 
WM793 + HES
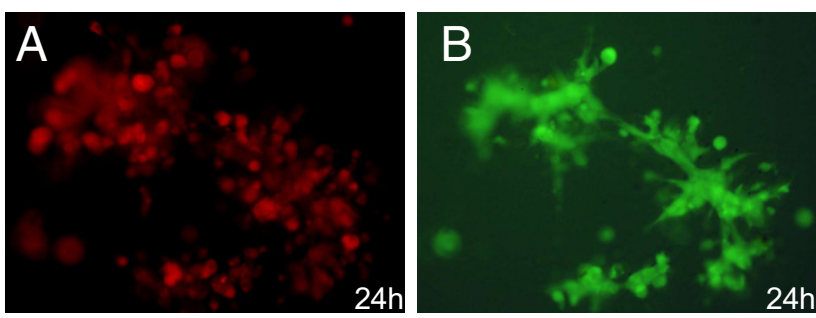

WM793 + HES
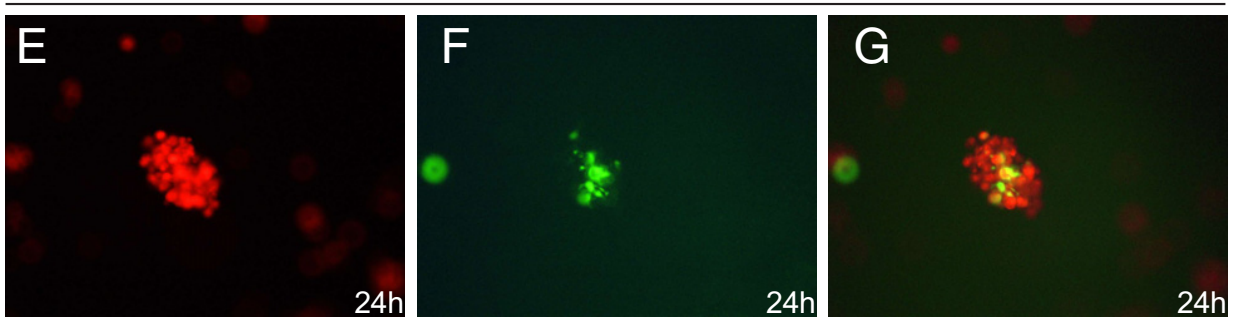

HAS

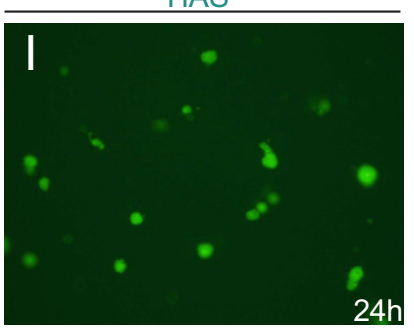

WM793 + HAS

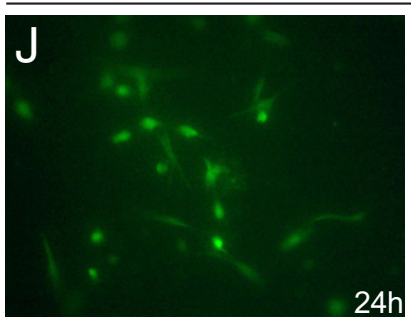

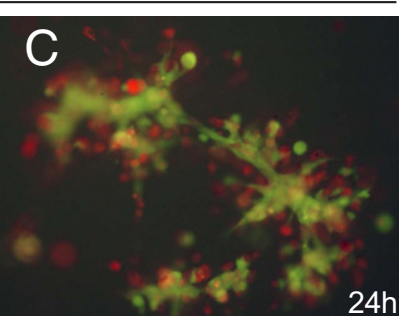

$24 \mathrm{~h}$

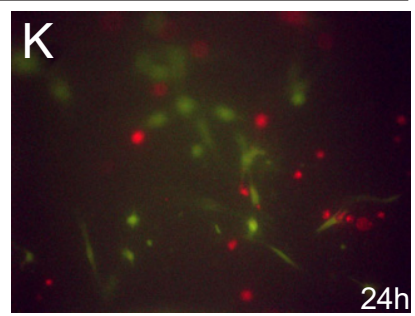

WM793 + HAS

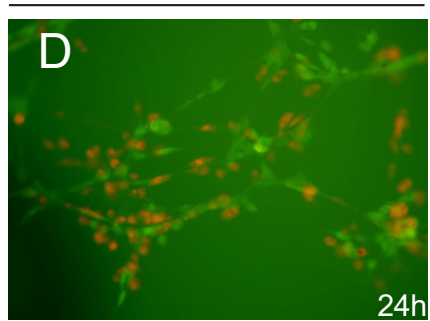

HES + WM793

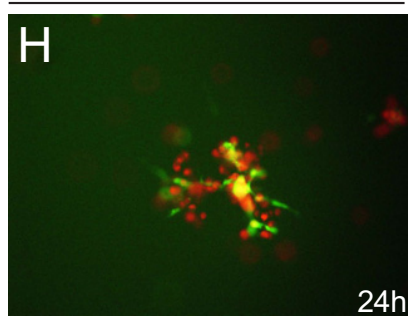

WM793 + HAS

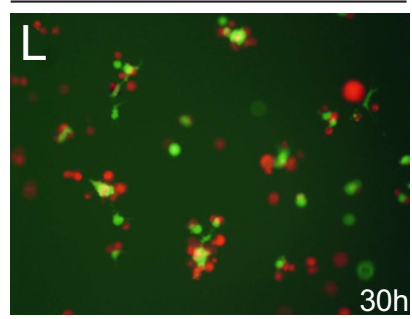

Figure 2. Growth patterns of fluorescent-labeled WM793 melanoma cells and fibroblasts, HES or HAS, cultured alone or together in 3D-Matrigel. A-C: Co-culture of WM793 (red) (A) and HES (green) (B) cells (1:1) in the middle of Matrigel for 24 hours; merged image of $\mathbf{A}$ and $\mathbf{B}$ (81.6\% $\pm 4.2 \%$ of the fibroblasts are elongated/activated in three randomly chosen fields, two independent experiments; C). D: Merged image of WM793 (red) and HAS (green) cells cultured together in the middle of Matrigel (74.4\% $\pm 5.1 \%$ of the fibroblasts are elongated). E-G: Co-culture of WM793 (red) (E) and HES (green) (F) cells seeded in the middle and on top of Matrigel, respectively; merged image of $\mathbf{E}$ and $\mathbf{F}(52.3 \% \pm 3.2 \%$ of the fibroblasts are elongated; G). Photographs focusing on melanoma cells in the middle of the gel. H: Co-culture of WM793 (red) and HES (green) cells seeded on top and in the middle of Matrigel, respectively $(54.2 \% \pm 6.5 \%$ of the fibroblasts are elongated); photograph focusing on melanoma cells on top of the gel. I: Culture of HAS cells alone (green) on top of Matrigel for 24 hours ( $<1 \%$ of the fibroblasts elongated). J and K: Co-culture of HAS (green; seeded on top of Matrigel) and WM793 (red; seeded in the middle of Matrigel) cells for 24 hours ( $42.5 \% \pm 9.5 \%$ of the fibroblasts are elongated). Photograph showing fibroblasts on the top ( $\mathbf{J})$ and melanoma cells and fibroblasts in the middle of Matrigel (K). L: Co-culture of WM793 and HAS cells (seeded on top and in the middle of Matrigel, respectively) for 30 hours $(49.0 \% \pm 3.6 \%$ of the fibroblasts are elongated; an independent experiment from that shown in $\mathbf{K})$. Photograph focusing on melanoma cells in the middle of the Matrigel. Original magnification, $\times 100$.

cells remained roundish, whereas the fibroblasts acquired the typical spindle-shaped morphological characteristics and the ability to invade (Figure 2, B and D; see also Supplemental Figure S4A at $h$ ttp://ajp.amjpathol.org). Indeed, it looked like the fibroblasts were the primary invading cells that formed the branched invasion network, a skeleton on which WM793 cells were adhered, like the leaves on a branch of a tree (Figure 2, C and D). Moreover, the leading cell in the invasion fronts appeared almost invariably to be a fibroblast. Also, during the first 24 hours, there was only a change in the invasive activity of the cells, with no significant increase in the number of cells, in response to the co-culture (see Supplemental Figure 4B at http://ajp.amjpathol.org). Similar results were also obtained when co-culturing WM115, SK-MEL-28, SKMEL-103, SK-MEL-147, or WM239 melanoma cells with the fibroblasts (see Supplemental Figure S5 at http:// ajp.amjpathol.org; data not shown). The SK-MEL-103 and SK-MEL147 cells also showed some invasion on their own in Matrigel (with an epithelial-mesenchymal transition-like conversion; data not shown), fitting with their aggressive growth pattern in immunocompromised mice. $^{23}$

In addition, we examined the invasive behavior of the fluorescent-labeled WM793 melanoma cells and HES fibroblasts when seeded separately, either melanoma cells in the middle of the Matrigel and fibroblasts on top (Figure 2, E-G) or vice versa (Figure 2H). Microscopic follow-up (at 2- to 8-hour intervals) revealed that the WM793 cells throve less well in the middle of the gel (under growth conditions more closely mimicking the situation in vivo) than on top of Matrigel (when directly exposed to serum), and that the fibroblasts became activated/spindle shaped more rapidly in the latter case (presumably as a result of more abundant secretion of cytokines/growth factors by the serum-stimulated melanoma cells). It also appeared that fibroblasts were the primarily migrating cells. After 24 hours of culture, small clusters of melanoma cells and fibroblasts in direct contact were again observed, in both growth conditions (Figure 2, $\mathrm{G}$ and $\mathrm{H}$ ). It was further confirmed by fluorescent labeling that the melanoma cells cultured within Matrigel 

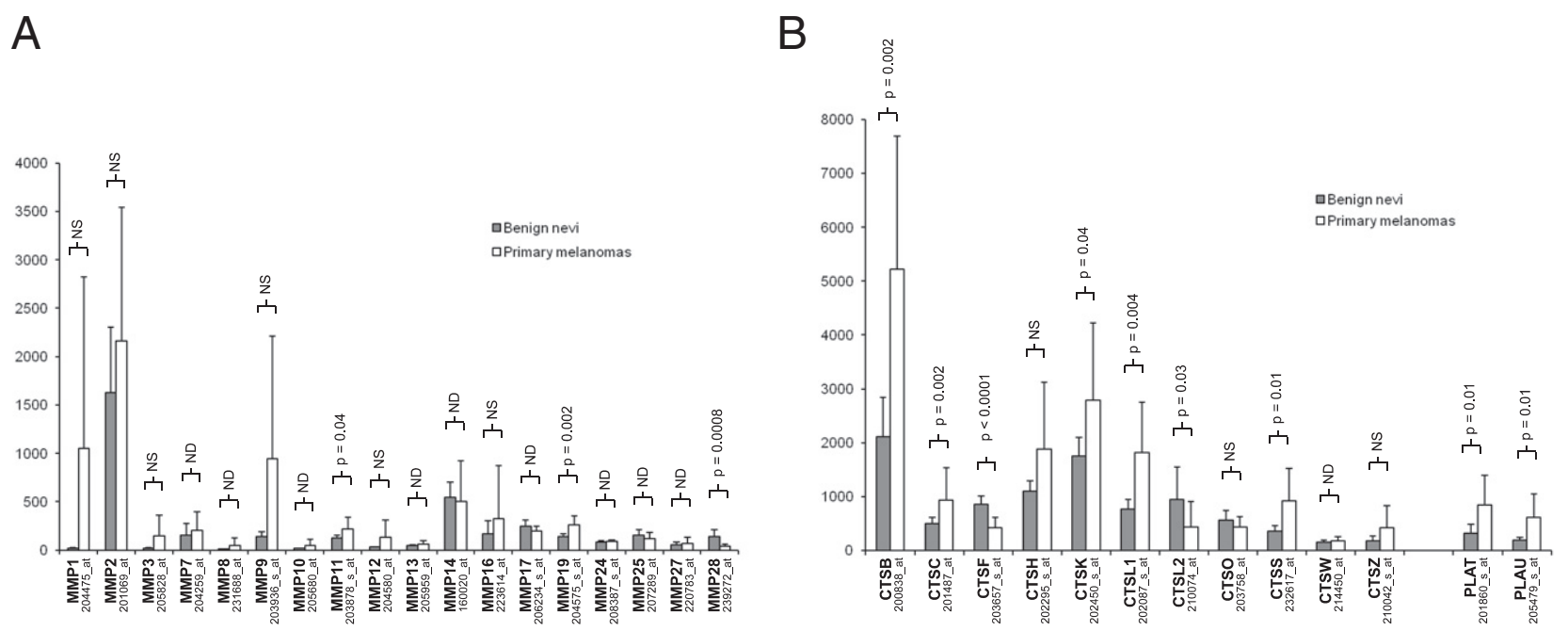

Figure 3. Gene expression analysis of proteases by Affymetrix HG U133 Plus 2.0 arrays in human benign nevi ( $n=12$ ) and primary melanomas (set $1 ; n=11$; Breslow's depth, $>2 \mathrm{~mm}$ ). Comparison of the mean mRNA expression levels of different members of MMPs (A) and cysteine cathepsins and PLAT and PLAU (B) in benign nevi and primary melanomas. The melanomas in this series have a median thickness of $7 \mathrm{~mm}$. ND, not determined (mean difference between groups, $<80$ ); NS, not significant. Error bars indicate SDs.

can activate the quiescent adult fibroblasts (HAS) cultured on top of the Matrigel (Figure 2, I and J) and induce their migration toward the melanoma cells in the middle of the gel (Figure 2, $\mathrm{K}$ and $\mathrm{L}$ ).

\section{Microarray Analysis of Proteases in Benign Nevi and Primary Melanomas}

To identify the physiologically relevant proteases potentially involved in melanoma invasion, we performed a genome-wide comparative gene expression analysis of proteases (nearly 600 in humans), exploiting the Affymetrix's Gene Ontology Molecular Function annotations and the MEROPS ${ }^{41}$ and the National Center for Biotechnology Information databases, in thick human melanomas and benign nevi, in two independent patient groups (sets 1 and 2 containing invasive melanomas with median Breslow's depths of 7 and $3.5 \mathrm{~mm}$, respectively). In foldchange analyses, the largest increase (14- to 59-fold) in protease gene expression in melanomas was found in MMP-1 (Figure 3A; see also Supplemental Figure S6A at http://ajp.amjpathol.org). Likewise, MMP-9 showed a marked up-regulation in many, but not all, of the primary melanomas, compared with the benign nevi (Figure 3A; see also Supplemental Figure S6A at http://ajp.amjpathol. org). However, because of the high variations of both of these MMPs, statistical significance was reached only for MMP-9 mRNA in one sample set. When our data on nevi were then analyzed against a third melanoma microarray data set $(n=10,>2 \mathrm{~mm}$ ) deposited in Data Banks, a statistically significant increase was observed for both MMP-1 and MMP-9 mRNAs (see Supplemental Figure S7A at $h$ ttp://ajp.amjpathol.org). Unexpectedly, the mRNA expression level of MMP-2, a putative prognostic marker, ${ }^{42,43}$ showed only a relatively small increase in the melanomas, and those of the membrane-type MMPs (MMP-14 to MMP-17) did not show consistent changes or remained unchanged in all three data sets (Figure $3 \mathrm{~A}$; see also Supplemental Figures S6A and S7A at http:// ajp.amjpathol.org). A severalfold increase was also detected in a disintegrin and metalloproteinase (ADAM) family member 12 in two of the melanoma series (sets 1 and 3 with a higher tumor thickness), and smaller changes in some other members of the ADAM and ADAMTS (a disintegrin and metalloproteinase with thrombospondin motif) family (see Supplemental Figure S8 at http://ajp.amjpathol.org; data not shown). The fibroblast activation protein $\alpha$, a serine protease selectively expressed in reactive stromal fibroblasts, showed a significant 3.9-fold increase in the set 1 melanomas (described later) and nearly significant 1.7- and 3.7-fold increases in the set 2 and 3 melanomas, respectively (data not shown).

Next, an analysis of the mRNA levels of the cathepsin family proteases revealed that cysteine cathepsins $B$ (CTSB) and L (CTSL1) were highly significantly $(P=$ 0.0018 and $P=0.0044$, respectively) up-regulated (both approximately 2.4-fold) in the primary melanomas compared with benign nevi, with cathepsin $B$ reaching the highest expression level/signal (Figure 3B). Similar results were obtained in analyses of the other series of melanomas (see Supplemental Figures S6B and S7B at http://ajp.amjpathol.org). In addition, the expression level of cysteine cathepsin S was statistically significantly (Figure 3B; see also Supplemental Figure S6B at http:// ajp.amjpathol.org) or nearly significantly $(P=0.0503)$ (see Supplemental Figure S7B at http://ajp.amjpathol.org) increased ( $\leq 2.5$-fold), and those of cathepsin L2/CTSL2 and cathepsin F were highly significantly decreased in all three melanoma series (Figure 3B; see also Supplemental Figures S6B and S7B at http://ajp.amjpathol.org). Furthermore, our microarray (and RT-PCR) analyses of primary melanoma cells and melanoma cell lines showed that they often expressed high levels of cathepsin B mRNA and moderate levels of cathepsin $L$ mRNA, whereas the expression of cathepsin S mRNA was con- 
Table 1. Proteases with Significantly Increased Expression (Twofold or More) in Thick Primary Melanomas (Set 1) Compared with Benign Nevi by SAM

\begin{tabular}{|c|c|c|c|c|c|}
\hline \multirow[b]{2}{*}{ Description (gene) } & \multirow[b]{2}{*}{ Probe set ID } & \multicolumn{2}{|c|}{ Mean $\pm S D$} & \multirow[b]{2}{*}{$\begin{array}{l}\text { Primary melanomas } \\
\text { versus nevi (fold) }\end{array}$} & \multirow[b]{2}{*}{$\begin{array}{l}\text { SAM } \\
\text { score }\end{array}$} \\
\hline & & Benign nevi & $\begin{array}{l}\text { Thick primary melanomas } \\
\qquad(>2 \mathrm{~mm})\end{array}$ & & \\
\hline Cathepsin B (CTSB) & 200839_s_at & $2658.1 \pm 901.1$ & $5890.8 \pm 2183.6$ & 2.22 & 4.640 \\
\hline $\begin{array}{l}\text { Membrane metalloendopeptidase } \\
(\mathrm{MME})\end{array}$ & 203435_s_at & $114.9 \pm 31.9$ & $337.9 \pm 140.7$ & 2.94 & 4.205 \\
\hline $\begin{array}{l}\text { Leucine aminopeptidase } 3 \\
\text { (LAP3) }\end{array}$ & 217933_s_at & $615.9 \pm 197.3$ & $1271.0 \pm 458.3$ & 2.06 & 4.195 \\
\hline $\begin{array}{l}\text { ADAM metallopeptidase with } \\
\text { thrombospondin type } 1 \text { motif, } 2 \\
\text { (ADAMTS2) }\end{array}$ & 226311_at & $158.0 \pm 49.2$ & $482.6 \pm 225.8$ & 3.05 & 4.158 \\
\hline Cathepsin B (CTSB) & 200838_at & $2113.9 \pm 731.5$ & $5224.3 \pm 2469.4$ & 2.47 & 4.113 \\
\hline AE binding protein 1 (AEBP1) & 201792_at & $918.7 \pm 249.7$ & $2086.8 \pm 939.9$ & 2.27 & 3.995 \\
\hline $\begin{array}{l}\text { Fibroblast-activation protein, } \alpha \\
(F A P)\end{array}$ & 209955_s_at & $103.8 \pm 33.4$ & $409.3 \pm 225.1$ & 3.94 & 3.969 \\
\hline $\begin{array}{l}\text { ADAM metallopeptidase domain } \\
19 \text { (ADAM19) }\end{array}$ & 209765_at & $79.4 \pm 15.9$ & $194.1 \pm 62.5$ & 2.45 & 3.827 \\
\hline Cathepsin L1 (CTSL1) & 202087_s_at & $771.5 \pm 171.2$ & $1812.4 \pm 945.7$ & 2.35 & 3.607 \\
\hline $\begin{array}{l}\text { ADAM metallopeptidase domain } \\
9 \text { (ADAM9) }\end{array}$ & 202381_at & $238.4 \pm 116.1$ & $522.5 \pm 202.8$ & 2.19 & 3.574 \\
\hline $\begin{array}{l}\text { ADAM metallopeptidase domain } \\
12 \text { (ADAM12) }\end{array}$ & 226777_at & $31.7 \pm 8.2$ & $281.2 \pm 204.5$ & 8.87 & 3.548 \\
\hline $\begin{array}{l}\text { Plasminogen activator, urokinase } \\
\quad(P L A U)\end{array}$ & 205479_s_at & $194.4 \pm 55.3$ & $612.2 \pm 434.4$ & 3.15 & 3.037 \\
\hline $\begin{array}{l}\text { ADAM metallopeptidase with } \\
\text { thrombospondin type } 1 \text { motif, } \\
12 \text { (ADAMTS12) }\end{array}$ & 226997_at & $91.1 \pm 16.0$ & $213.6 \pm 100.0$ & 2.35 & 3.022 \\
\hline Transferrin receptor (TFRC) & 208691_at & $861.0 \pm 632.8$ & $2206.1 \pm 1367.1$ & 2.56 & 2.995 \\
\hline $\begin{array}{l}\text { Signal peptidase complex } \\
\text { subunit } 3 \text { homolog (SPCS3) }\end{array}$ & 222753_s_at & $96.7 \pm 20.3$ & $203.4 \pm 82.6$ & 2.10 & 2.972 \\
\hline $\begin{array}{l}\text { Proteasome subunit, } \beta \text { type, } 9 \\
\text { (PSMB9) }\end{array}$ & 204279_at & $317.4 \pm 148.5$ & $785.0 \pm 484.3$ & 2.47 & 2.962 \\
\hline Cathepsin S (CTSS) & 232617_at & $363.3 \pm 104.2$ & $922.4 \pm 606.6$ & 2.54 & 2.960 \\
\hline $\begin{array}{l}\text { Plasminogen activator, tissue } \\
\quad(P \perp A T)\end{array}$ & 201860_s_at & $326.9 \pm 158.8$ & $843.4 \pm 546.6$ & 2.58 & 2.936 \\
\hline $\begin{array}{l}\text { Complement component } 1, r \\
\text { subcomponent }(C 1 R)\end{array}$ & 212067_s_at & $604.0 \pm 187.0$ & $1323.7 \pm 830.2$ & 2.19 & 2.800 \\
\hline $\begin{array}{l}\text { Caspase 1, apoptosis-related } \\
\text { cysteine peptidase (CASP1) }\end{array}$ & 211368_s_at & $256.5 \pm 119.6$ & $631.7 \pm 407.7$ & 2.46 & 2.795 \\
\hline $\begin{array}{l}\text { Proteasome subunit, } \beta \text { type, } 10 \\
\text { (PSMB10) }\end{array}$ & 202659_at & $271.2 \pm 98.0$ & $557.8 \pm 302.7$ & 2.06 & 2.771 \\
\hline Transferrin receptor (TFRC) & 207332_s_at & $654.6 \pm 384.2$ & $1530.4 \pm 987.0$ & 2.34 & 2.750 \\
\hline $\begin{array}{l}\text { Ubiquitin-specific peptidase } 34 \\
\text { (USP34) }\end{array}$ & 233595_at & $152.1 \pm 92.8$ & $348.4 \pm 189.3$ & 2.29 & 2.701 \\
\hline $\begin{array}{l}\text { CASP8 and FADD-like apoptosis } \\
\text { regulator (CFLAR) }\end{array}$ & 239629_at & $128.0 \pm 84.2$ & $472.4 \pm 393.8$ & 3.69 & 2.700 \\
\hline $\begin{array}{l}\text { Leishmanolysin-like } \\
\text { (metallopeptidase M8 family) } \\
(\text { LMLN) }\end{array}$ & 244881_at & $177.4 \pm 65.6$ & $356.4 \pm 178.2$ & 2.01 & 2.697 \\
\hline Complement factor I (CFI) & 203854_at & $61.2 \pm 13.9$ & $200.8 \pm 140.3$ & 3.28 & 2.686 \\
\hline $\begin{array}{l}\text { Complement component } 1, \text { s } \\
\text { subcomponent (C1S) }\end{array}$ & 208747_s_at & $1146.4 \pm 416.8$ & $2332.3 \pm 1444.1$ & 2.03 & 2.659 \\
\hline $\begin{array}{l}\text { Plasminogen activator, urokinase } \\
\quad(P L A U)\end{array}$ & 211668_s_at & $124.2 \pm 42.9$ & $382.3 \pm 295.0$ & 3.08 & 2.653 \\
\hline
\end{tabular}

${ }^{*}$ Cutoff for significance: $q$ value $=0$, with a median false-discovery rate of $0 \%$.

stantly low/nondetectable in them all (data not shown). Thus, the increase in cathepsin S mRNA was likely accomplished by stromal cells. Also, the expression levels of UPA (PLAU) and tissue-type plasminogen activator (PLAT) mRNAs were significantly increased (2- to 3.5fold) in the VGP melanomas in all three melanoma series (Figure 3B; see also Supplemental Figures S6B and S7B at $h$ ttp://ajp.amjpathol.org).

Analyses of the same three melanoma and benign nevi patient groups by SAM revealed that CTSB was invari- ably among the most significantly up-regulated genes (Table 1; data not shown). CTSL1, cysteine cathepsin S, PLAU, PLAT, AE binding protein 1, fibroblast activation protein $\alpha$, and ADAM9 also scored relatively high in all three melanoma series. The scoring of CTSL1, however, appeared to be related to the thickness of melanomas, being among the top genes in the set 1 and 3 and somewhat lower in the set 2 melanomas (with a lower median thickness), in concert with the fold-change and statistical analysis results previously described (Figure 
Table 2. Proteases with Significantly Increased Expression in Thick Compared with Thin Primary Melanomas by SAM

\begin{tabular}{|c|c|c|c|c|c|c|}
\hline \multirow[b]{2}{*}{ Description (gene) } & \multirow[b]{2}{*}{ Probe set ID } & \multicolumn{2}{|c|}{ Mean $\pm \mathrm{SD}$} & \multirow{2}{*}{$\begin{array}{l}\text { Thick versus } \\
\text { thin } \\
\text { melanomas } \\
\text { (fold) }\end{array}$} & \multicolumn{2}{|c|}{ SAM data* } \\
\hline & & $\begin{array}{l}\text { Thin primary } \\
\text { melanomas } \\
(<2 \mathrm{~mm})\end{array}$ & $\begin{array}{c}\text { Thick primary } \\
\text { melanomas } \\
(>2 \mathrm{~mm})\end{array}$ & & $\begin{array}{l}\text { SAM } \\
\text { score }\end{array}$ & $q$ Value \\
\hline $\begin{array}{l}\text { Membrane metalloendopeptidase } \\
\quad(M M E)\end{array}$ & 203435_s_at & $181.2 \pm 53.3$ & $421.1 \pm 150.2$ & 2.32 & 3.448 & 0.00325 \\
\hline $\mathrm{AE}$ binding protein $1(A E B P 1)$ & 201792_at & $1197.4 \pm 679.2$ & $2210.6 \pm 958.1$ & 1.85 & 2.553 & 0.00325 \\
\hline Cathepsin L1 (CTSL1) & 202087_s_at & $1036.7 \pm 387.4$ & $1985.3 \pm 1055.1$ & 1.91 & 2.440 & 0.00325 \\
\hline Cathepsin B (CTSB) & 200838_at & $3154.6 \pm 1575.3$ & $5424.7 \pm 2448.4$ & 1.72 & 2.357 & 0.00325 \\
\hline Plasminogen activator, tissue (PLAT) & 201860_s_at & $320.7 \pm 224$ & $751.6 \pm 482.4$ & 2.34 & 2.247 & 0.00325 \\
\hline $\begin{array}{l}\text { Plasminogen activator, urokinase } \\
\quad(P L A U)\end{array}$ & 205479_s_at & $297.4 \pm 71.3$ & $643.9 \pm 442.9$ & 2.17 & 2.079 & 0.00358 \\
\hline $\begin{array}{l}\text { ADAM metallopeptidase domain } 12 \\
\text { (ADAM12) }\end{array}$ & 226777_at & $85.5 \pm 92.2$ & $250.3 \pm 179.9$ & 2.93 & 1.984 & 0.00358 \\
\hline $\begin{array}{l}\text { Plasminogen activator, urokinase } \\
\quad(P L A U)\end{array}$ & 211668_s_at & $166.5 \pm 53.1$ & $386.0 \pm 296.0$ & 2.32 & 1.873 & 0.00464 \\
\hline Fibroblast activation protein, $\alpha(F A P)$ & 209955_s_at & $248.1 \pm 143.6$ & $441.8 \pm 233.2$ & 1.78 & 1.829 & 0.00464 \\
\hline Complement factor I $(\mathrm{CFI})$ & 203854_at & $114.3 \pm 37.2$ & $235.9 \pm 169.4$ & 2.06 & 1.629 & 0.00464 \\
\hline
\end{tabular}

The thin melanomas $(n=9)$ had a median thickness of $1.2 \mathrm{~mm}$, and the thick melanomas $(n=11)$ had a median thickness of $7.0 \mathrm{~mm}$.

${ }^{*}$ Cutoff for significance: median false-discovery rate of $0.5 \%$.

3B; see also Supplemental Figures S6B and S7B at $h$ ttp:// ajp.amjpathol.org). Again, ADAMs 12 and 19, ADAMTSs 2 and 12, and MME (membrane metallo-endopeptidase, also called CD10/neprilysin/NEP/CALLA) scored high specifically in the set 1 and 3 melanomas (with a higher median thickness) (Table 1; data not shown).

Next, we analyzed the protease expression levels in thinner $(<2 \mathrm{~mm})$ melanomas and compared them with those in the thicker $(>2 \mathrm{~mm}$ ) ones to find out which of the proteases (Table 1) could truly be associated with melanoma progression/invasion (and not just, as possible, with melanoma development). Notably, the mRNA levels of cathepsins CTSB and CTSL1, plasminogen activators PLAU and PLAT, MME, AE binding protein 1, ADAM12, and fibroblast activation protein $\alpha$ were most significantly increased in the thicker melanomas (Table 2), suggesting that these proteases might primarily play a role in the progression of invasive VGP melanomas. Also, 10 of the 11 patients with $>2-\mathrm{mm}$ melanomas and only 1 of the 9 patients with $<2$-mm tumors have thus far had metastasis during the follow-up of 7 to 10 years, associating the previously described proteases with metastasis. This association was further strengthened by our SAM analysis of the melanomas that have or have not metastasized (Soikkeli et al., unpublished data). Because the Breslow's depth of invasion predicts metastasis $^{44}$ and is the most powerful predictor of survival in patients with clinically localized melanoma, ${ }^{45,46}$ we tested whether the expression levels of cathepsins B and $L$ could predict the patient outcome. Interestingly, despite the small sample size, a statistically significant association between a high level of CTSB mRNA expression and poor survival was observed (see Supplemental Figure S9 at $h t t p: / / a j p . a m j p a t h o l . o r g)$. It remains to be studied in a larger patient cohort (eg, by using a TMA-based approach ${ }^{47}$ ) whether cathepsin B and/or the other proteases could serve as independent prognostic indicators.

\section{Effects of MMP and Cathepsin B/L Inhibitors on the Invasive Growth of WM793 Cells and Fibroblasts}

Because WM793 melanoma cells displayed some invasive capacity in 3D-Matrigel when cultured alone for several days, we first studied the effects of various inhibitors of MMPs (which also inhibit ADAMs, ADAMTSs, and $M M E)^{48,49}$ and of cysteine cathepsins on their invasion. Based on our preliminary dose-response analyses, we selected the maximal inhibitor concentrations that did not yet interfere with cell proliferation in tissue culture for the analyses. The wide-spectrum MMP inhibitor GM6001 (Ilomastat), but not its negative control, clearly inhibited the invasive growth of the WM793 cells (see Supplemental Figure S1, C and D, at http://ajp.amjpathol.org). Likewise, a specific inhibitor of cathepsin B, CA-074, which is a cell membrane-impermeable inhibitor (but might enter cells during a prolonged culture), ${ }^{50}$ caused a clear inhibition of invasion (see Supplemental Figure S1E at http://ajp. amjpathol.org). Most notably, however, the cathepsin B inhibitor CA-074Me, a cell membrane-permeable prodrug that is converted by intracellular esterases to the active inhibitor ${ }^{51}$ appeared to cause complete inhibition of the invasive growth (see Supplemental Figure S1F at http://ajp.amjpathol.org). Also, the cell membrane-permeable cathepsin L inhibitor I (Z-FF-FMK) caused nearly complete inhibition of invasion (see Supplemental Figure S1G at $h t t p: / / a j p . a m j p a t h o l . o r g$ ).

Then, we studied the inhibitor effects on WM793 cells co-cultured with HAS or HES. Surprisingly, the widespectrum MMP inhibitors (GM6001, BB-2516, and BB3103) did not significantly affect the invasive growth of the cells (Figure 4, A-D; see also Supplemental Figures S10, A-D, and S11, A-C, at http://ajp.amjpathol.org). As a further surprise, the cell membrane-impermeable cathepsin B inhibitor, CA-074, also had no significant effect during the first 3 days of treatment (Figure 4E; see also 


\section{WM793 + HAS}
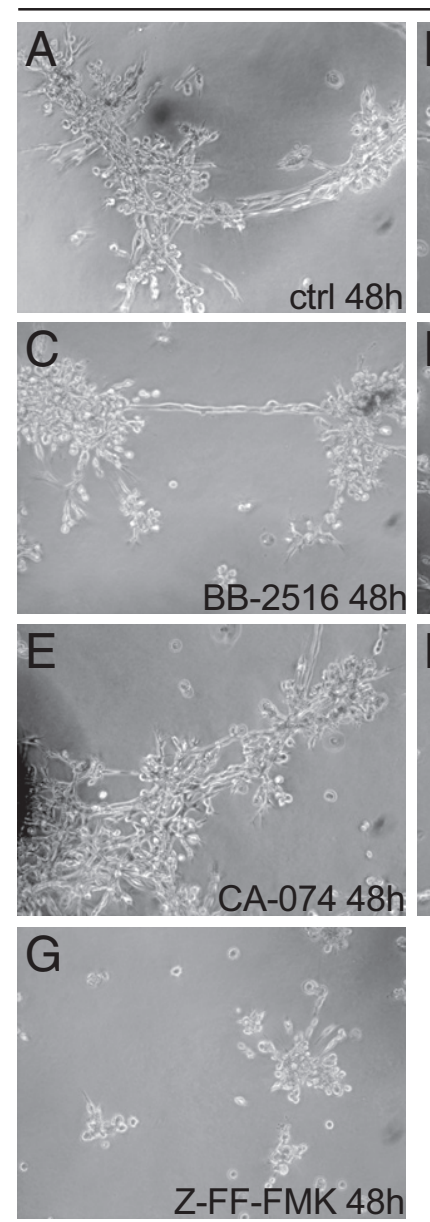

Figure 4. Effects of various MMP and cysteine cathepsin inhibitors on the invasive growth of WM793 and HAS cells co-cultured in the middle of 3D-Matrigel. Co-culture without inhibitor (A) and with MMP inhibitor, GM6001 (Ilomastat, $10 \mu \mathrm{mol} / \mathrm{L} ; \mathbf{B}$ ), MMP inhibitor, BB-2516 (Marimastat, 10 $\mu \mathrm{mol} / \mathrm{L}$; C), MMP inhibitor, BB-3103 (10 $\mu \mathrm{mol} / \mathrm{L}$; D), cell membrane-impermeable cathepsin B inhibitor, CA-074 $(5 \mu \mathrm{mol} / \mathrm{L} ; \mathbf{E})$, cell membrane-permeable cathepsin B inhibitor, CA- $074 \mathrm{Me}(5 \mu \mathrm{mol} / \mathrm{L} ; \mathbf{F})$, and cathepsin L inhibitor I $(15 \mu \mathrm{mol} / \mathrm{L} ; \mathbf{G})$ for 48 hours. Original magnification, $\times 100$. Dramatically reduced formation and size of the fibroblast-melanoma cell colonies with cell membrane-permeable cathepsin $\mathrm{B}$ and $\mathrm{L}$ inhibitors are seen.

Supplemental Figures S10E and S11D at http://ajp. amjpathol.org), whereas the cell membrane-permeable CA-074Me inhibitor completely blocked the interaction between the melanoma cells and fibroblasts, and subsequent invasive growth (Figure 4F; see also Supplemental Figures S10F and S11E at http://ajp.amjpathol.org). The cathepsin $L$ inhibitor I also caused extensive inhibition of the invasive growth (Figure 4G; see also Supplemental Figures S10G and S11F at http://ajp.amjpathol.org). Moreover, similar results/inhibitor sensitivities were also obtained when examining the effects of MMP (GM6001), cathepsin B (CA-074 and CA-074Me), and cathepsin L (Z-FF-FMK) inhibitors on the invasive growth of WM115, SK-MEL-28, SK-MEL-103, or SK-MEL-147 cells co-cultured with HES (data not shown). The inhibitor effects started to be seen already at much lower concentrations, as shown for CA-074Me (see Supplemental Figure S12 at http://ajp.amjpathol.org). Also, the inhibitor of uPA (5 to 15
WM793 + HAS
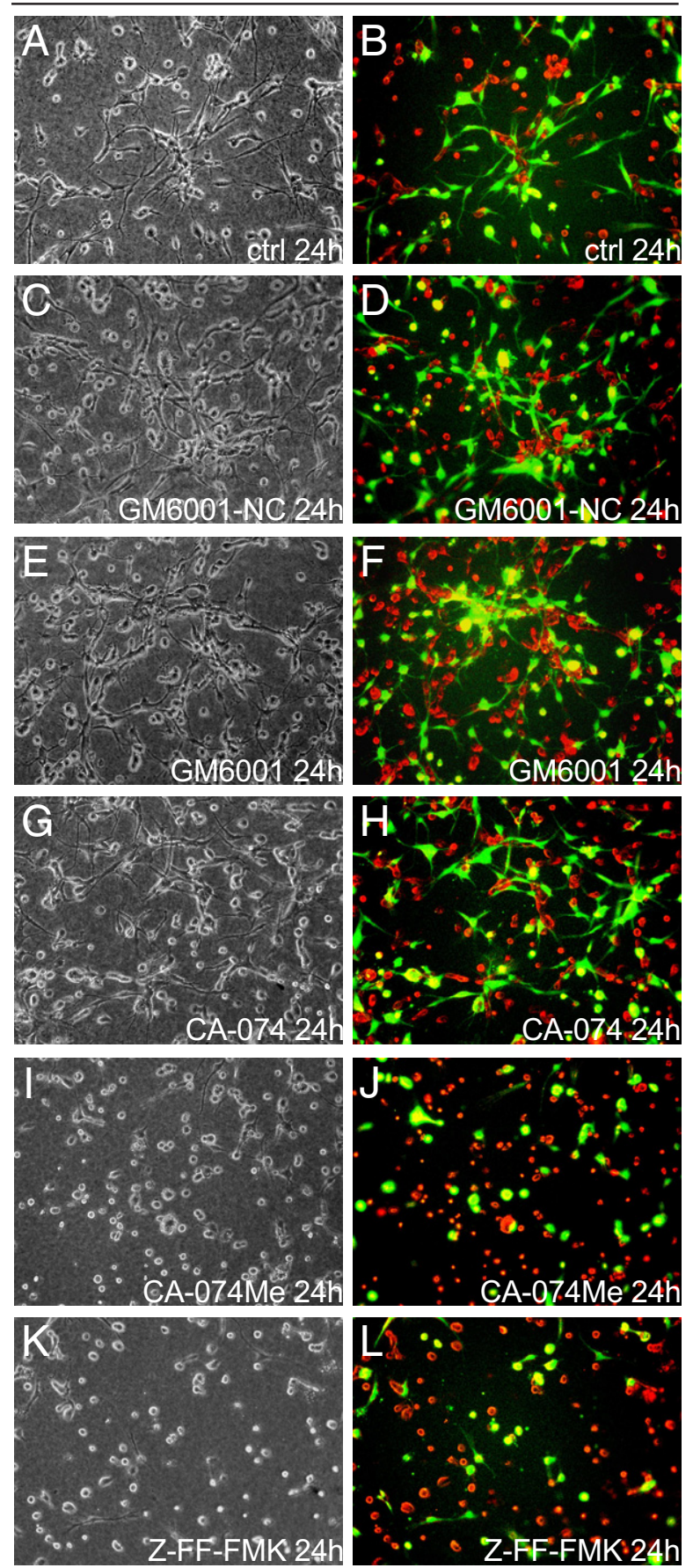

Figure 5. Effects of various MMP and cysteine cathepsin inhibitors on the invasive growth of fluorescent-labeled WM793 (red) and HAS (green) cells co-cultured (1:1) in a 3D gel composed of Matrigel $(2 \mathrm{mg} / \mathrm{mL})$ and collagen-I $(2 \mathrm{mg} / \mathrm{mL})$. Co-culture without inhibitors $(80.7 \% \pm 3.8 \%$ of the fibroblasts elongated/activated in three randomly chosen fields, two independent experiments; $\mathbf{A}$ and $\mathbf{B}$ ) and with MMP inhibitor, GM6001, negative control (10 $\mu \mathrm{mol} / \mathrm{L} ; 76.5 \% \pm 2.6 \%$ elongated fibroblasts; no significant inhibition, $P=$ 0.1935 ; C and D), MMP inhibitor, GM6001 (Ilomastat, $10 \mu \mathrm{mol} / \mathrm{L} ; 77.0 \% \pm$ $2.4 \%$ elongated fibroblasts; no significant inhibition, $P=0.2354 ; \mathbf{E}$ and $\mathbf{F}$ ), cell membrane-impermeable cathepsin B inhibitor, CA-074 $(5 \mu \mathrm{mol} / \mathrm{L}$; $73.6 \% \pm 2.8 \%$ elongated fibroblasts; no significant inhibition, $P=0.0644 ; \mathbf{G}$ and $\mathbf{H})$, cell membrane-permeable cathepsin B inhibitor CA-074Me (5 $\mu \mathrm{mol} / \mathrm{L} ; 9.2 \% \pm 2.5 \%$ elongated fibroblasts; significant inhibition, $P<0.0001$; $\mathbf{I}$ and $\mathbf{J}$ ), and cathepsin L inhibitor I ( $15 \mu \mathrm{mol} / \mathrm{L} ; 22.1 \% \pm 6.7 \%$ elongated fibroblasts; significant inhibition, $P=0.0007 ; \mathbf{K}$ and $\mathbf{L}$ ) for 24 hours. Both phase-contrast and fluorescence images are shown. Original magnification, $\times 100$. 
Cathepsin B

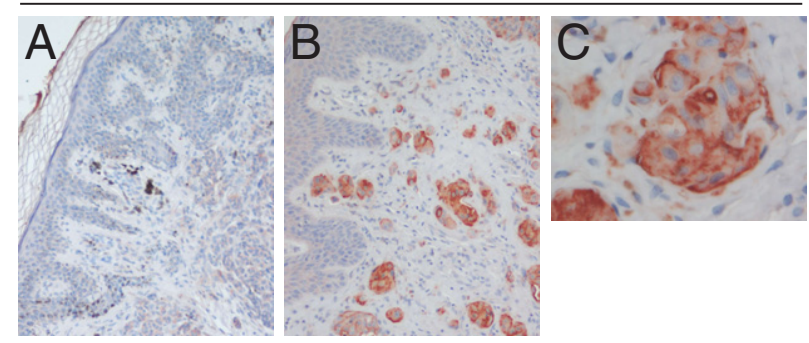

Cathepsin L

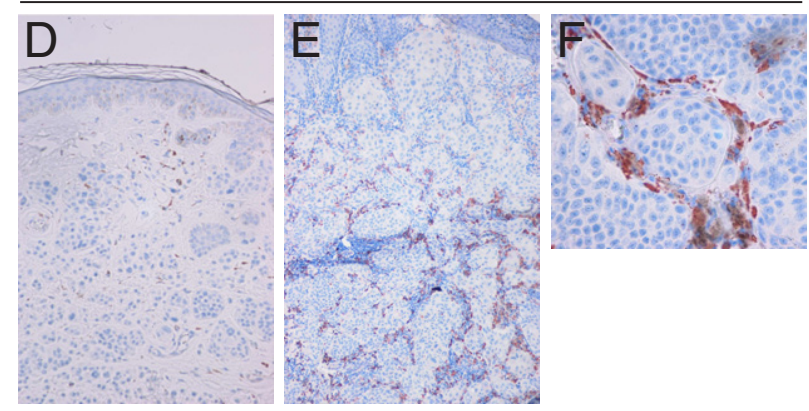

Figure 6. The IHC analysis of cathepsin B and L protein expression in human benign nevi and VGP primary melanomas. A: Immunostaining of cathepsin B in benign nevus. B and C: Immunostaining of cathepsin B in primary melanoma. D: Immunostaining of cathepsin L in benign nevus. $\mathbf{E}$ and $\mathbf{F}$ : Immunostaining of cathepsin $\mathrm{L}$ in primary melanoma. Original magnification: $\times 100(\mathbf{A}, \mathbf{B}, \mathbf{D}, \mathbf{E}) ; \times 400(\mathbf{C}$ and $\mathbf{F})$.

$\mu \mathrm{mol} / \mathrm{L}$ ) had only a small inhibitory effect on the invasive growth of the co-cultured cells (data not shown).

In addition, we tested the inhibitor effects in a composite 3D-Matrigel/collagen-I gel, using fluorescent-labeled melanoma cells (red) and fibroblasts (green) to differentiate between the effects on the two cell types. Overall, the inhibitor effects in this matrix (Figure 5; see also Supplemental Figure S13 at http://ajp.amjpathol.org) were similar to those seen in 3D-Matrigel. Fluorescent images confirmed that the GM6001 and CA-074 inhibitors did not significantly affect the activation state/morphological characteristics of the fibroblasts (Figure 5, B, D, F, and $\mathrm{H}$; see also Supplemental Figure S13, B, D, F, and $H$, at http://ajp.amjpathol.org). In contrast, the cathepsin B inhibitor, CA-074Me, and cathepsin L inhibitor I blocked activation of the fibroblasts, as evidenced by their remaining round (Figure 5, J and L; see also Supplemental Figure S13, J and L, at http://ajp.amjpathol.org). Altogether, these findings, combined with the observed increases in the expression of cathepsins B and $L$ in actual human melanomas, suggested a critical role for cathepsins $B$ and $L$ in invasive growth.

\section{Immunostaining of Cathepsins $B$ and $L$ in Primary Human VGP Melanomas and Benign Nevi}

We next IHC stained primary VGP melanomas and benign nevi for cathepsins $B$ and $L$ to confirm the increased mRNA expression levels at the protein level, and to identify the cells expressing these two proteases. In the past, because of the lack of suitable antibodies for staining of formalin-fixed, paraffin-embedded human melanomas, reliable staining for cathepsins $B$ and $L$ has been only reported on frozen sections (infiltrated with $30 \%$ sucrose and $1 \%$ gum arabicum). ${ }^{52}$ Frozen sections are, however, not recommended for histological evaluation of melanomas. In our analyses, benign nevus cells and the surrounding stromal fibroblasts expressed low levels or no immunoreactive cathepsin B (Figure 6A). In contrast, the malignant melanoma cells, but not the surrounding fibroblasts, expressed cathepsin B at elevated levels, with some cells exhibiting a high intensity of cytoplasmic and membrane staining (Figure 6, B and C). The melanoma cells at the circumferential margin of the tumor cell nests (ie, the melanoma cells adjacent to the stroma) also often showed a stronger staining of cathepsin B than those in the tumor center (see Supplemental Figure S14 at http:// ajp.amjpathol.org). The expression of cathepsin $L$ was also low in benign nevus cells and surrounding fibroblasts (Figure 6D). In primary melanomas, the expression of cathepsin $L$ was low to moderate in the melanoma cells, but the stromal fibroblasts surrounding the melanoma cell nests showed high-intensity staining for cathepsin L. Specifically, the staining intensity of cathepsin $L$ in fibroblasts was increased with the depth of the melanoma cell invasion (Figure 6, E and F).

\section{TGF- $\beta$ Drives the Interaction between WM793 Melanoma Cells and Fibroblasts and Their Invasive Growth}

Given that TGF- $\beta$ regulates fibroblast activation, ${ }^{53,54}$ we studied the possibility of TGF- $\beta$ signaling stimulating cathepsin $L$ expression in fibroblasts (because the fibroblasts adjacent to the invading melanoma cells abundantly expressed cathepsin L). Indeed, TGF- $\beta$ stimulated cathepsin $L$ mRNA expression in skin fibroblasts grown in serum-free fibroblast growth medium (containing defined growth factors) to a similar extent to the addition of $\mathrm{CM}$
A

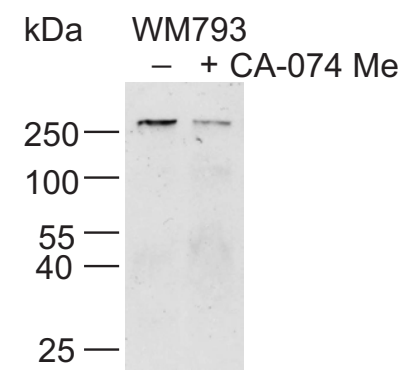

B

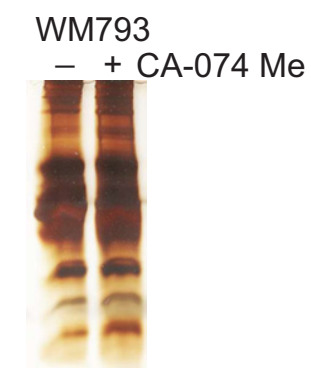

Figure 7. The cell membrane-permeable inhibitor, CA-074Me, of cathepsin $\mathrm{B}$ inhibits the production/secretion of the TGF- $\beta$ large latent complex by WM793 melanoma cells. WM793 cells were grown on Matrigel-coated plates in serum-free medium with or without CA- $074 \mathrm{Me}$ for 48 hours, after which the secreted proteins are analyzed for the amount of TGF- $\beta$ complexes by immunoblotting (A) and total proteins by silver staining (as a control; $\mathbf{B}$ ). The amount of the TGF- $\beta$ large latent complex (migrating at a molecular weight of approximately $270 \mathrm{kDa}$ ) is markedly decreased, whereas the production of the total proteins remains constant or is slightly increased by the CA-074Me treatment. Similar results were obtained in two independent experiments. 
from WM793 melanoma cells (see Supplemental Figure S15A at $h$ ttp://ajp.amjpathol.org). Reciprocally, we found that the growth factors/CM from activated fibroblasts (HES) stimulated the expression of cathepsin B in melanoma (WM793) cells (see Supplemental Figure S15B at http://ajp.amjpathol.org). Because cathepsin B, in turn, activates latent TGF- $\beta,{ }^{55,56}$ we studied the effects of cathepsin B inhibitors on TGF- $\beta$ production/processing in WM793 cells. Interestingly, we found that the cell membrane-permeable CA-074Me inhibitor markedly reduced the production/secretion of the TGF- $\beta$ large latent complex $^{57,58}$ which is the major form of TGF- $\beta$ secreted ${ }^{59}$ (Figure 7). Thus, the amount of the TGF- $\beta$ precursor activatable by cathepsin $\mathrm{B}$ (or other proteases) in $\mathrm{CM}$ was already reduced. Next, we studied the importance of TGF- $\beta$ in the regulation of the invasiveness of co-cultured WM793 cells and fibroblasts in Matrigel. Significantly, inhibition of the TGF- $\beta$ signaling by increasing concentrations of a specific inhibitor of the TGF- $\beta$ receptor-I/ ALK5 resulted in a dose-dependent inhibition of the cell-cell interactions and invasive growth of the cells (Figure 8; see also Supplemental Figure S16 at http://ajp.amjpathol.org). Likewise, co-culturing WM793 cells and fibroblasts in the presence of a pan-neutralizing TGF- $\beta$ antibody abolished the activation of fibroblasts and the invasion-promoting interaction between the melanoma cells and fibroblasts (see Supplemental Figure S17, A-F, at http://ajp.amjpathol.org). Furthermore, the subsequent invasive growth of the cells was effectively inhibited in the presence of the TGF- $\beta$ neutralizing antibodies (see Supplemental Figure S17, $\mathrm{G}-\mathrm{I}$, at $h$ ttp://ajp.amjpathol.org).

\section{Discussion}

The importance of studying tumor cell invasion in proper microenvironmental and cellular contexts is increasingly recognized. 4,7,60 Herein, we found that the invasive growth of melanoma cells in 3D-Matrigel/collagen-I matrices is enhanced by skin fibroblasts. The melanoma cells apparently served as initiators of the reciprocal interplay with fibroblasts, because the fibroblasts alone did not thrive in Matrigel but became activated by the cocultured melanoma cells. It further appeared that the fibroblasts were hijacked to facilitate the invasion of melanoma cells, as inferred from the invasion patterns. The activated fibroblasts formed the branching network of invasion, and the melanoma cells were riding on the fibroblasts. A similar kind of fibroblast-led invasion has also been reported for squamous cell carcinoma cells. ${ }^{61}$ The early VGP WM793 cells could, however, also invade on their own in Matrigel when stimulated with growth factors/CM from fibroblasts. Furthermore, the metastatic SK-MEL-103 and SK-MEL-147 cells could also clearly invade Matrigel in the absence of fibroblast growth factors. Under these conditions, the cells appeared to undergo an EMT-like morphological change. Thus, melanoma cells can use different invasion modes. Nevertheless, it is clear that fibroblasts play a dominant role in the regulation of the invasive process of melanoma cells, either through direct or indirect (paracrine) interac-
A WM793 + HES
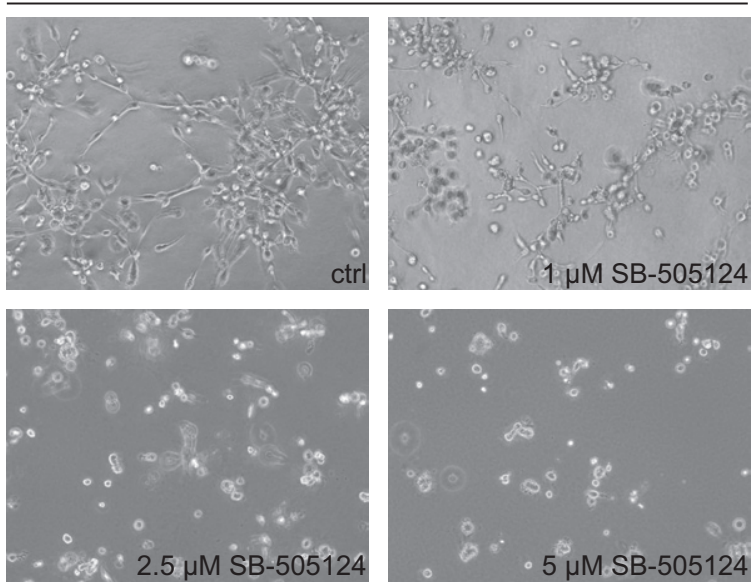

$\mathrm{B}$

WM793 + HAS
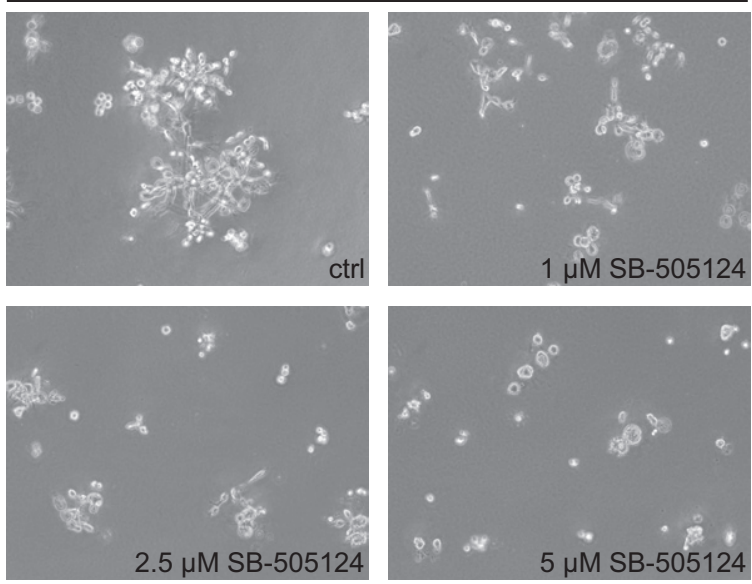

Figure 8. Effect of specific TGF- $\beta$ receptor I/ALK5 inhibitor (SB-505124) on the invasive growth of WM793 cells and HES or HAS, co-cultured (1:1) in the middle of 3D-Matrigel. A: Co-culture of WM793 and HES cells without SB-505124 and with SB-505124 at 1, 2.5, and $5 \mu \mathrm{mol} / \mathrm{L}$ concentrations for 36 hours. B: Co-culture of WM793 and HAS cells without SB-505124, and with SB-505124 at $1,2.5$, and $5 \mu \mathrm{mol} / \mathrm{L}$ concentrations for 36 hours. Original magnification, $\times 100$. The dramatically reduced formation and size of the fibroblast-melanoma cell colonies with the ALK5 inhibitor are shown. ctrl, control.

tions with the melanoma cells. In two-dimensional-coculture systems, the ability of the melanoma cells to activate fibroblasts is reported to be melanoma stage dependent. ${ }^{62}$ However, we found that in 3D-Matrigel, the invasive growth of both the early VGP (WM115 and WM793) and metastatic (SK-MEL-28, SK-MEL-103, SKMEL-147, and WM239) melanoma cells was highly stimulated by fibroblasts. In actual human tumors, we similarly found that the interaction between the melanoma cells and fibroblasts is likely to be important for the invasive growth of both the primary melanomas ${ }^{35}$ and distant metastases. ${ }^{24}$

Herein, we also studied which proteases might be involved in the invasive growth of human melanomas. In our gene expression analysis of all proteases in benign nevi and invasive melanomas, the most marked changes were seen in MMP-1 and MMP-9, both of which are expressed by fibroblasts. ${ }^{16}$ In addition, MMP-1 may be highly expressed by some melanoma cell lines (eg, 
WM793) and primary melanoma cells (unpublished data). MMPs have been generally associated with invasion, because they can destruct all components of the ECM and basement membranes, ${ }^{63,64}$ but they may also be involved in many other processes, such as angiogenesis $^{16,65}$ and stromal cell-mediated tumor growth/survival. ${ }^{66}$ Until recently, inhibition of MMPs was believed to be a promising strategy for cancer therapy, but most of the clinical trials performed with wide-spectrum MMP inhibitors have yielded disappointing results. ${ }^{64,67}$ Interestingly, in our studies, we found that the MMP inhibitors inhibited the inherent low-invasive capacity of the WM793 melanoma cells when cultured alone, but, surprisingly, not the fibroblast-accelerated invasive growth. These data imply that the master regulators of invasion in human melanomas are fibroblast-derived/induced proteases not belonging to the MMP family. The same also holds for ADAMs, ADAMTSs, and MME, which are at least partially inhibited by the MMP inhibitors used. ${ }^{48,49}$ However, individual MMPs may have different functions, even totally opposing ones (eg, MMP-8 exerting a tumor-suppressive function). ${ }^{68}$ Therefore, it would be important to be able to test specific inhibition of only selected MMPs, such as MMP-1 and MMP-9, that were up-regulated in our study. Likewise, we should also use specific inhibitors for MME, the expression of which we found to be significantly upregulated (by SAM) in more advanced primary melanomas, fitting with an earlier $\mathrm{IHC}$ study ${ }^{69}$ Interestingly, stromal MME expression may also be an early indicator of progression/recurrence of breast carcinomas in situ, ${ }^{70}$ provoking similar studies in early-stage melanomas.

Most interestingly, we found cysteine cathepsins B, L, and $S$ that are lysosomal proteases to be commonly up-regulated in human invasive melanomas. Furthermore, we found the expression of cathepsins $B$ and $L$ to significantly correlate with metastasis, and that of cathep$\sin B$ to correlate with reduced patient survival. Cathepsins $B$ and $L$ degrade basement membrane and $E C M$ proteins and are increased in many cancers. ${ }^{19}$ Furthermore, blocking the activities of cathepsin $B$ and $L$ has significantly inhibited the invasion of various tumor cells in different model systems, ${ }^{25,50,71-75}$ as in this study. In transformed cells, cathepsins B and $L$ are translocated to the cell surface (caveolae and podosomes) or secreted, ${ }^{75-77}$ which could explain their capability to degrade ECM proteins and promote invasion. On the other hand, an intracellular form of cathepsin B is shown to be important for tumor cell invasion in Matrigel, ${ }^{50}$ and cysteine cathepsins can also degrade ECM proteins intracellularly after endocytosis. ${ }^{19}$ In addition, cathepsins $B$ and $L$ may be involved in the degradation of ECM proteins and in the regulation of various signaling cascades associated with invasion and/or other cellular processes. ${ }^{17,78,79}$ Also, investigation of both tumor and stromal cells may be important for identifying the key proteases involved in tumor invasion and metastasis, as shown in this study. Intriguingly, we found that the cell membrane-permeable cathepsin B and $L$ inhibitors, but not the cell membraneimpermeable cathepsin B inhibitor, block the melanoma cell-fibroblast interplay and subsequent invasive growth in 3D-Matrigel/collagen-I, making the intracellular (and possible exosomal) cathepsins $B$ and $L$ potentially good therapeutic targets. Altogether, our in vitro and in vivo studies in human melanomas suggest that cathepsins B and $L$ play a central and pivotal role in the invasion process, giving a reason to believe that, in addition to acting as protein-degrading enzymes, they act high in the hierarchical organization of the proteases and may, thus, control the activation of other proteases, such as MMPs and $u P A,{ }^{80,81}$ or other invasion-related signaling events.

More important, our $\mathrm{IHC}$ analyses confirmed the increased expression of cathepsins $B$ and $L$ in the VGP melanomas. In the tumor tissues, the predominant expression of cathepsin $\mathrm{B}$ was confined to the melanoma cells and that of cathepsin $L$ was confined to the surrounding fibroblasts. Interestingly, the cathepsin $L$ staining was mostly detected in the fibroblast tracts lining the invading melanoma cell nests/chains, with the intensity of the staining increasing with the depth of melanoma cell invasion. Thus, the activation of fibroblasts and concomitant cathepsin $L$ expression appears to be a dynamic process, peaking at the invasion fronts. Previously, we have reported a similar staining pattern for procollagen-I, tenascin-C, and fibronectin (all produced by fibroblasts), forming tubular tracks embracing the invading melanoma cells. ${ }^{24,35}$ This kind of specific organization of the activated fibroblasts and localization of the cathepsin $L$ are likely to be of importance for the melanoma cell invasion, enabling cathepsin L, together with cathepsin B expressed by the melanoma cells, to effectively clear specific paths/channels through which the following melanoma cells can easily disseminate. Cathepsin $L$ expression is also up-regulated in CAFs of breast cancer, ${ }^{82}$ speaking for the generality of the finding. Furthermore, we found the cathepsin L inhibitor Z-FF-FMK, although also inhibiting cathepsin B at higher concentrations, to effectively block the invasive growth of co-cultured melanoma cells and fibroblasts. Thus, considering therapeutic strategies, it seems best to block the activity of both of these cathepsins. Moreover, knockout experiments in a pancreatic cancer model have shown cathepsin B and $L$ to have nonredundant roles in invasion. ${ }^{72}$ However, a recent unexpected finding that the knockout of cathepsin $L$ in mouse skin may result in increased tumorigenesis ${ }^{83}$ may be a complicating factor for exploiting cathepsin L inhibitors in cancer therapeutics. However, in humans, there is also a cathepsin L-like enzyme, cathepsin L2 (also called cathepsin V), that shows an even higher homology to mouse cathepsin $L,{ }^{84}$ making direct extrapolations of the cathepsin $L$ knockout experiments to the human situation difficult. Furthermore, we found that, in contrast to cathepsin L/CTSL1, the expression of cathepsin L2/CTSL2 was significantly down-regulated in human melanomas compared with benign nevi, suggesting that the encoded two homologs of cathepsin $L$ may have distinct functions. Thus, we should develop specific inhibitors for cathepsin L/CTSL1 for selectively blocking its increased expression in melanomas.

Our data further suggest a key role for TGF- $\beta$ in triggering and promoting the co-invasive growth of WM793 cells and fibroblasts, strengthening our earlier findings on clinical melanoma specimens. ${ }^{24}$ Melanoma cells (includ- 
ing WM793) secrete TGF- $\beta$ and exhibit constitutive autocrine TGF- $\beta$ stimulation. ${ }^{24,85-87}$ Herein, we made the interesting finding that intracellular cathepsin B activity is important for the production/secretion of TGF- $\beta$ (the large latent complex) in WM793 cells. Furthermore, we found that blocking TGF- $\beta$ signaling with a TGF- $\beta$ receptor-I/ ALK5 inhibitor or TGF- $\beta$-neutralizing antibodies effectively inhibited the activation of fibroblasts and the melanoma-fibroblast cell interaction-promoted invasive growth. However, although TGF- $\beta$ may be necessary, it is apparently not sufficient alone to activate fibroblasts, because we found TGF- $\beta$ to stimulate cathepsin L expression in the fibroblasts only in the presence of other growth factors. We, therefore, propose that melanoma cells initiate the process by secreting latent TGF- $\beta$ (in a cathepsin B-regulated manner) that is further converted extracellularly by cathepsin $B,{ }^{55,56}$ MMP-9, ${ }^{63}$ or other proteases $^{88}$ into the active form, which then, together with other growth factors, activates the fibroblasts. Because the activated fibroblasts/myofibroblasts also exhibit an autocrine TGF- $\beta$ signaling loop, ${ }^{54}$ the melanoma cell-fibroblast interplay will result in a feed-forward amplification of TGF- $\beta$ signaling in both cell types and concomitant up-regulation of the cathepsin $B$ and $L$ expression.

In conclusion, we found that the invasion of melanoma cells is promoted and guided by fibroblasts, and that this process is dependent on TGF- $\beta$ signaling and cysteine cathepsins B/L but not on MMP activity. Furthermore, our genome-wide microarray and $\mathrm{IHC}$ analyses of human melanomas and benign nevi demonstrated significantly increased expression of cathepsin $B$ and $L$ in invasive melanomas. Cathepsin B was predominantly expressed by the melanoma cells, and cathepsin $L$ was predominantly expressed by the CAFs. The expression levels of cathepsin B further correlated with shortened patient survival. In light of these data, it remains interesting to determine whether inhibition of cathepsins $B$ and $L$, and of TGF- $\beta$ signaling (particularly together to avoid a compensatory increase in cathepsin $L$ on depletion of cathepsin $\mathrm{B}^{89}$ and to block the observed TGF- $\beta$ feed-forward amplification loop) could be a viable and effective therapeutic approach for inhibiting melanoma-fibroblast cross talk and subsequent tumor cell invasion/dissemination. TGF- $\beta$ pan-antibodies and receptor kinase inhibitors are already in clinical trials, ${ }^{90}$ but cathepsin $\mathrm{B} / \mathrm{L}$ inhibitors are still in preclinical testing. ${ }^{91}$ Significantly, these treatments should also work irrespective of the melanoma cell genotype and phenotype, based on our studies with cells with BRAF or NRAS mutations (and other mutations) (http://www.sanger.ac.uk/genetics/CGP/cosmic, The Wellcome Trust Sanger Institute, Cambridge, UK, last accessed June 10, 2012) and different phenotypes. ${ }^{92}$ It will be important to further study this potential therapeutic aspect in vivo, because there is a high degree of genetic heterogeneity in melanomas that complicates the personalized-medicine approaches. Also, it would be interesting to study whether this kind of inhibition of the interplay between melanoma cells and fibroblasts (by targeting the key pro-invasive molecules and TGF- $\beta$ signaling in both cell types) could add to the therapeutic efficacy/outcome of the recently launched BRAFV600E mutation-specific inhibitors in melanomas. ${ }^{13}$

\section{Acknowledgments}

We thank Kirsi Ravanko for IHC staining of cathepsin L and Merja Haukka and Leena Saikko for technical assistance.

\section{References}

1. Bissell MJ, Radisky D: Putting tumours in context. Nat Rev Cancer 2001, 1:46-54

2. Mueller MM, Fusenig NE: Friends or foes: bipolar effects of the tumour stroma in cancer. Nat Rev Cancer 2004, 4:839-849

3. TIsty TD, Coussens LM: Tumor stroma and regulation of cancer development. Annu Rev Pathol 2006, 1:119-150

4. Polyak K, Haviv I, Campbell IG: Co-evolution of tumor cells and their microenvironment. Trends Genet 2009, 25:30-38

5. Bhowmick NA, Neilson EG, Moses HL: Stromal fibroblasts in cancer initiation and progression. Nature 2004, 432:332-337

6. Orimo A, Weinberg RA: Stromal fibroblasts in cancer: a novel tumorpromoting cell type. Cell Cycle 2006, 5:1597-1601

7. Kalluri R, Zeisberg M: Fibroblasts in cancer. Nat Rev Cancer 2006, 6:392-401

8. Villanueva J, Herlyn M: Melanoma. Encyclopedia of Life Sciences (ELS). Chichester, John Wiley \& Sons Ltd, 2009

9. Thompson JF, Scolyer RA, Kefford RF: Cutaneous melanoma. Lancet 2005, 365:687-701

10. Davies H, Bignell GR, Cox C, Stephens P, Edkins S, Clegg S, et al: Mutations of the BRAF gene in human cancer. Nature 2002, 417:949954

11. Berger MF, Levin JZ, Vijayendran K, Sivachenko A, Adiconis $X$, Maguire J, Johnson LA, Robinson J, Verhaak RG, Sougnez C, Onofrio RC, Ziaugra L, Cibulskis K, Laine E, Barretina J, Winckler W, Fisher DE, Getz G, Meyerson M, Jaffe DB, Gabriel SB, Lander ES, Dummer R, Gnirke A, Nusbaum C, Garraway LA: Integrative analysis of the melanoma transcriptome. Genome Res 2010, 20:413-427

12. Scott KL, Nogueira C, Heffernan TP, van Doorn R, Dhakal S, Hanna JA, Min C, Jaskelioff M, Xiao Y, Wu CJ, Cameron LA, Perry SR, Zeid R, Feinberg T, Kim M, Vande Woude G, Granter SR, Bosenberg M, Chu GC, DePinho RA, Rimm DL, Chin L: Proinvasion metastasis drivers in early-stage melanoma are oncogenes. Cancer Cell 2011, 20:92-103

13. Alcala AM, Flaherty KT: BRAF inhibitors for the treatment of metastatic melanoma: clinical trials and mechanisms of resistance. Clin Cancer Res 2012, 18:33-39

14. de Vries TJ, Quax PH, Denijn M, Verrijp KN, Verheijen JH, Verspaget HW, Weidle UH, Ruiter DJ, van Muijen GN: Plasminogen activators, their inhibitors, and urokinase receptor emerge in late stages of melanocytic tumor progression. Am J Pathol 1994, 144:70-81

15. Shi Z, Stack MS: Urinary-type plasminogen activator (UPA) and its receptor (UPAR) in squamous cell carcinoma of the oral cavity. Biochem J 2007, 407:153-159

16. Kessenbrock K, Plaks V, Werb Z: Matrix metalloproteinases: regulators of the tumor microenvironment. Cell 2010, 141:52-67

17. Mason SD, Joyce JA: Proteolytic networks in cancer. Trends Cell Biol 2011, 21:228-237

18. Turk V, Kos J, Turk B: Cysteine cathepsins (proteases): on the main stage of cancer? Cancer Cell 2004, 5:409-410

19. Mohamed MM, Sloane BF: Cysteine cathepsins: multifunctional enzymes in cancer. Nat Rev Cancer 2006, 6:764-775

20. Frohlich E: Proteases in cutaneous malignant melanoma: relevance as biomarker and therapeutic target. Cell Mol Life Sci 2010, 67:39473960

21. Hsu M, Elder DE, Herlyn M: The Wistar (WM) melanoma cell lines. Human Cell Culture. Edited by JMaB Palsson. London, Kluwer Academic Publishers, 1999, pp 259-274 
22. Gorden A, Osman I, Gai W, He D, Huang W, Davidson A, Houghton AN, Busam K, Polsky D: Analysis of BRAF and N-RAS mutations in metastatic melanoma tissues. Cancer Res 2003, 63:3955-3957

23. Fernandez Y, Verhaegen M, Miller TP, Rush JL, Steiner P, Opipari AW Jr, Lowe SW, Soengas MS: Differential regulation of noxa in normal melanocytes and melanoma cells by proteasome inhibition: therapeutic implications. Cancer Res 2005, 65:6294-6304

24. Soikkeli J, Podlasz P, Yin M, Nummela P, Jahkola T, Virolainen S, Krogerus L, Heikkila P, von Smitten K, Saksela O, Holtta E: Metastatic outgrowth encompasses COL-I, FN1, and POSTN up-regulation and assembly to fibrillar networks regulating cell adhesion, migration, and growth. Am J Pathol 2010, 177:387-403

25. Ravanko K, Jarvinen K, Helin J, Kalkkinen N, Holtta E: Cysteine cathepsins are central contributors of invasion by cultured adenosylmethionine decarboxylase-transformed rodent fibroblasts. Cancer Res 2004, 64:8831-8838

26. Zajchowski DA, Bartholdi MF, Gong Y, Webster L, Liu HL, Munishkin A, Beauheim C, Harvey S, Ethier SP, Johnson PH: Identification of gene expression profiles that predict the aggressive behavior of breast cancer cells. Cancer Res 2001, 61:5168-5178

27. Paasinen-Sohns A, Kaariainen E, Yin M, Jarvinen K, Nummela P, Holtta $E$ : Chaotic neovascularization induced by aggressive fibrosarcoma cells overexpressing S-adenosylmethionine decarboxylase. Int J Biochem Cell Biol 2011, 43:441-454

28. Seton-Rogers SE, Lu Y, Hines LM, Koundinya M, LaBaer J, Muthuswamy SK, Brugge JS: Cooperation of the ErbB2 receptor and transforming growth factor beta in induction of migration and invasion in mammary epithelial cells. Proc Natl Acad Sci U S A 2004, 101: 1257-1262

29. Wang SE, Shin I, Wu FY, Friedman DB, Arteaga CL: HER2/Neu (ErbB2) signaling to Rac1-Pak1 is temporally and spatially modulated by transforming growth factor beta. Cancer Res 2006, 66:9591-9600

30. Kielosto M, Nummela P, Katainen R, Leaner V, Birrer MJ, Holtta E: Reversible regulation of the transformed phenotype of ornithine decarboxylase- and ras-overexpressing cells by dominant-negative mutants of C-Jun. Cancer Res 2004, 64:3772-3779

31. Soikkeli J, Lukk M, Nummela P, Virolainen S, Jahkola T, Katainen R, Harju L, Ukkonen E, Saksela O, Holtta E: Systematic search for the best gene expression markers for melanoma micrometastasis detection. J Pathol 2007, 213:180-189

32. Tusher VG, Tibshirani R, Chu G: Significance analysis of microarrays applied to the ionizing radiation response. Proc Natl Acad Sci U S A 2001, 98:5116-5121

33. MAQC Consortium, Shi L, Reid LH, Jones WD, Shippy R, Warrington JA, et al: The MicroArray Quality Control (MAQC) project shows interand intraplatform reproducibility of gene expression measurements. Nat Biotechnol 2006, 24:1151-1161

34. Nummela P, Lammi J, Soikkeli J, Saksela O, Laakkonen P, Hölttä E: Transforming growth factor beta-induced (TGFBI) is an anti-adhesive protein regulating the invasive growth of melanoma cells. Am J Pathol 2012, 180:1663-1674

35. Kaariainen E, Nummela $P$, Soikkeli J, Yin M, Lukk M, Jahkola T, Virolainen S, Ora A, Ukkonen E, Saksela O, Holtta E: Switch to an invasive growth phase in melanoma is associated with tenascin-C, fibronectin, and procollagen-I forming specific channel structures for invasion. J Pathol 2006, 210:181-191

36. Sinha AA, Wilson MJ, Gleason DF, Reddy PK, Sameni M, Sloane BF: Immunohistochemical localization of cathepsin B in neoplastic human prostate. Prostate 1995, 26:171-178

37. Wandel E, Raschke A, Hildebrandt G, Eberle J, Dummer R, Anderegg $U$, Saalbach A: Fibroblasts enhance the invasive capacity of melanoma cells in vitro. Arch Dermatol Res 2002, 293:601-608

38. Eves P, Katerinaki E, Simpson C, Layton C, Dawson R, Evans G, Mac Neil S: Melanoma invasion in reconstructed human skin is influenced by skin cells: investigation of the role of proteolytic enzymes. Clin Exp Metastasis 2003, 20:685-700

39. Li L, Dragulev B, Zigrino P, Mauch C, Fox JW: The invasive potential of human melanoma cell lines correlates with their ability to alter fibroblast gene expression in vitro and the stromal microenvironment in vivo. Int J Cancer 2009, 125:1796-1804

40. Lulevich V, Shih YP, Lo SH, Liu GY: Cell tracing dyes significantly change single cell mechanics. J Phys Chem B 2009, 113:6511-6519
41. Rawlings ND, Barrett AJ, Bateman A: MEROPS: the database of proteolytic enzymes, their substrates and inhibitors. Nucleic Acids Res 2012, 40:D343-D350

42. Gould Rothberg BE, Bracken MB, Rimm DL: Tissue biomarkers for prognosis in cutaneous melanoma: a systematic review and metaanalysis. J Natl Cancer Inst 2009, 101:452-474

43. Vaisanen A, Kuvaja P, Kallioinen M, Turpeenniemi-Hujanen T: A prognostic index in skin melanoma through the combination of matrix metalloproteinase-2, Ki67, and p53. Hum Pathol 2011, 42:1103-1111

44. Breslow A: Thickness, cross-sectional areas and depth of invasion in the prognosis of cutaneous melanoma. Ann Surg 1970, 172:902-908

45. Balch CM, Gershenwald JE, Soong SJ, Thompson JF, Atkins MB, Byrd DR, Buzaid AC, Cochran AJ, Coit DG, Ding S, Eggermont AM, Flaherty KT, Gimotty PA, Kirkwood JM, McMasters KM, Mihm MC Jr, Morton DL, Ross MI, Sober AJ, Sondak VK: Final version of 2009 AJCC melanoma staging and classification. J Clin Oncol 2009, 27: 6199-6206

46. Spatz A, Stock N, Batist G, van Kempen LC: The biology of melanoma prognostic factors. Discov Med 2010, 10:87-93

47. Alonso SR, Ortiz P, Pollan M, Perez-Gomez B, Sanchez L, Acuna MJ, Pajares R, Martinez-Tello FJ, Hortelano CM, Piris MA, RodriguezPeralto JL: Progression in cutaneous malignant melanoma is associated with distinct expression profiles: a tissue microarray-based study. Am J Pathol 2004, 164:193-203

48. Saghatelian A, Jessani N, Joseph A, Humphrey M, Cravatt BF: Activity-based probes for the proteomic profiling of metalloproteases. Proc Natl Acad Sci U S A 2004, 101:10000-10005

49. Fisher JF, Mobashery S: Recent advances in MMP inhibitor design Cancer Metastasis Rev 2006, 25:115-136

50. Szpaderska AM, Frankfater A: An intracellular form of cathepsin B contributes to invasiveness in cancer. Cancer Res 2001, 61:34933500

51. Buttle DJ, Murata M, Knight CG, Barrett AJ: CA074 methyl ester: a proinhibitor for intracellular cathepsin B. Arch Biochem Biophys 1992, 299:377-380

52. Frohlich E, Schlagenhauff B, Mohrle M, Weber E, Klessen C, Rassner G: Activity, expression, and transcription rate of the cathepsins B, D, $H$, and $L$ in cutaneous malignant melanoma. Cancer 2001, 91:972982

53. Tuxhorn JA, Ayala GE, Smith MJ, Smith VC, Dang TD, Rowley DR: Reactive stroma in human prostate cancer: induction of myofibroblast phenotype and extracellular matrix remodeling. Clin Cancer Res 2002, 8:2912-2923

54. Kojima Y, Acar A, Eaton EN, Mellody KT, Scheel C, Ben-Porath I, Onder TT, Wang ZC, Richardson AL, Weinberg RA, Orimo A: Autocrine TGF-beta and stromal cell-derived factor-1 (SDF-1) signaling drives the evolution of tumor-promoting mammary stromal myofibroblasts. Proc Natl Acad Sci U S A 2010, 107:20009-20014

55. Guo M, Mathieu PA, Linebaugh B, Sloane BF, Reiners JJ Jr: Phorbol ester activation of a proteolytic cascade capable of activating latent transforming growth factor-betaL a process initiated by the exocytosis of cathepsin B. J Biol Chem 2002, 277:14829-14837

56. Andl CD, McCowan KM, Allison GL, Rustgi AK: Cathepsin B is the driving force of esophageal cell invasion in a fibroblast-dependent manner. Neoplasia 2010, 12:485-498

57. Kanzaki T, Olofsson A, Moren A, Wernstedt C, Hellman U, Miyazono $\mathrm{K}$, Claesson-Welsh L, Heldin $\mathrm{CH}$ : TGF-beta 1 binding protein: a component of the large latent complex of TGF-beta 1 with multiple repeat sequences. Cell 1990, 61:1051-1061

58. Annes JP, Munger JS, Rifkin DB: Making sense of latent TGFbeta activation. J Cell Sci 2003, 116:217-224

59. Miyazono $\mathrm{K}$, Olofsson $\mathrm{A}$, Colosetti $\mathrm{P}$, Heldin $\mathrm{CH}$ : A role of the latent TGF-beta 1-binding protein in the assembly and secretion of TGFbeta 1. EMBO J 1991, 10:1091-1101

60. De Wever O, Mareel M: Role of tissue stroma in cancer cell invasion. J Pathol 2003, 200:429-447

61. Gaggioli C, Hooper S, Hidalgo-Carcedo C, Grosse R, Marshall JF, Harrington K, Sahai E: Fibroblast-led collective invasion of carcinoma cells with differing roles for RhoGTPases in leading and following cells. Nat Cell Biol 2007, 9:1392-1400

62. Cornil I, Theodorescu D, Man S, Herlyn M, Jambrosic J, Kerbel RS: Fibroblast cell interactions with human melanoma cells affect tumor cell growth as a function of tumor progression. Proc Natl Acad Sci U S A 1991, 88:6028-6032 
63. Stamenkovic I: Matrix metalloproteinases in tumor invasion and metastasis. Semin Cancer Biol 2000, 10:415-433

64. Coussens LM, Fingleton B, Matrisian LM: Matrix metalloproteinase inhibitors and cancer: trials and tribulations. Science 2002, 295 2387-2392

65. Jodele S, Blavier L, Yoon JM, DeClerck YA: Modifying the soil to affect the seed: role of stromal-derived matrix metalloproteinases in cancer progression. Cancer Metastasis Rev 2006, 25:35-43

66. Basset P, Bellocq JP, Wolf C, Stoll I, Hutin P, Limacher JM, Podhajcer OL, Chenard MP, Rio MC, Chambon P: A novel metalloproteinase gene specifically expressed in stromal cells of breast carcinomas. Nature 1990, 348:699-704

67. Overall CM, Kleifeld O: Tumour microenvironment-opinion: validating matrix metalloproteinases as drug targets and anti-targets for cancer therapy. Nat Rev Cancer 2006, 6:227-239

68. Palavalli LH, Prickett TD, Wunderlich JR, Wei X, Burrell AS, Porter-Gill P, Davis S, Wang C, Cronin JC, Agrawal NS, Lin JC, Westbroek W, Hoogstraten-Miller S, Molinolo AA, Fetsch P, Filie AC, O'Connell MP, Banister CE, Howard JD, Buckhaults P, Weeraratna AT, Brody LC Rosenberg SA, Samuels Y: Analysis of the matrix metalloproteinase family reveals that MMP8 is often mutated in melanoma. Nat Genet 2009, 41:518-520

69. Bilalovic N, Sandstad B, Golouh R, Nesland JM, Selak I, Torlakovic EE: CD10 protein expression in tumor and stromal cells of malignant melanoma is associated with tumor progression. Mod Pathol 2004, 17:1251-1258

70. Witkiewicz AK, Freydin B, Chervoneva I, Potoczek M, Rizzo W, Rui H, Brody JR, Schwartz GF, Lisanti MP: Stromal CD10 and SPARC expression in ductal carcinoma in situ (DCIS) patients predicts disease recurrence. Cancer Biol Ther 2010, 10:391-396

71. Dennhofer R, Kurschat $P$, Zigrino $P$, Klose A, Bosserhoff A, van Muijen G, Krieg T, Mauch C, Hunzelmann N: Invasion of melanoma cells into dermal connective tissue in vitro: evidence for an important role of cysteine proteases. Int J Cancer 2003, 106:316-323

72. Gocheva V, Zeng W, Ke D, Klimstra D, Reinheckel T, Peters C, Hanahan D, Joyce JA: Distinct roles for cysteine cathepsin genes in multistage tumorigenesis. Genes Dev 2006, 20:543-556

73. Bell-McGuinn KM, Garfall AL, Bogyo M, Hanahan D, Joyce JA: Inhibition of cysteine cathepsin protease activity enhances chemotherapy regimens by decreasing tumor growth and invasiveness in a mouse model of multistage cancer. Cancer Res 2007, 67:7378-7385

74. Matarrese P, Ascione B, Ciarlo L, Vona R, Leonetti C, Scarsella M, Mileo AM, Catricala C, Paggi MG, Malorni W: Cathepsin B inhibition interferes with metastatic potential of human melanoma: an in vitro and in vivo study. Mol Cancer 2010, 9:207

75. Lankelma JM, Voorend DM, Barwari T, Koetsveld J, Van der Spek AH, De Porto AP, Van Rooijen G, Van Noorden CJ: Cathepsin L, target in cancer treatment? Life Sci 2010, 86:225-233

76. Mason RW, Gal S, Gottesman MM: The identification of the major excreted protein (MEP) from a transformed mouse fibroblast cell line as a catalytically active precursor form of cathepsin L. Biochem $J$ 1987, 248:449-454

77. Roshy S, Sloane BF, Moin K: Pericellular cathepsin B and malignant progression. Cancer Metastasis Rev 2003, 22:271-286

78. Reiser J, Adair B, Reinheckel T: Specialized roles for cysteine cathepsins in health and disease. J Clin Invest 2010, 120:3421-3431

79. Turk V, Stoka V, Vasiljeva O, Renko M, Sun T, Turk B, Turk D: Cysteine cathepsins: from structure, function and regulation to new frontiers. Biochim Biophys Acta 2012, 1824:68-88

80. Murphy G, Ward R, Gavrilovic J, Atkinson S: Physiological mechanisms for metalloproteinase activation. Matrix Suppl 1992, 1:224-230

81. Kobayashi $H$, Ohi H, Sugimura M, Shinohara H, Fujii T, Terao T: Inhibition of in vitro ovarian cancer cell invasion by modulation of urokinase-type plasminogen activator and cathepsin B. Cancer Res 1992, 52:3610-3614

82. Singer CF, Gschwantler-Kaulich D, Fink-Retter A, Haas C, Hudelist G, Czerwenka K, Kubista E: Differential gene expression profile in breast cancer-derived stromal fibroblasts. Breast Cancer Res Treat 2008 , 110:273-281

83. Dennemarker J, Lohmuller T, Mayerle J, Tacke M, Lerch MM, Coussens LM, Peters C, Reinheckel T: Deficiency for the cysteine protease cathepsin $L$ promotes tumor progression in mouse epidermis. Oncogene 2010, 29:1611-1621

84. Yasuda Y, Li Z, Greenbaum D, Bogyo M, Weber E, Bromme D: Cathepsin V, a novel and potent elastolytic activity expressed in activated macrophages. J Biol Chem 2004, 279:36761-36770

85. Rodeck U, Nishiyama T, Mauviel A: Independent regulation of growth and SMAD-mediated transcription by transforming growth factor beta in human melanoma cells. Cancer Res 1999, 59:547-550

86. Berking C, Takemoto R, Schaider H, Showe L, Satyamoorthy K, Robbins $P$, Herlyn M: Transforming growth factor-beta1 increases survival of human melanoma through stroma remodeling. Cancer Res 2001, 61:8306-8316

87. Javelaud D, Alexaki VI, Mauviel A: Transforming growth factor-beta in cutaneous melanoma. Pigment Cell Melanoma Res 2008, 21:123-132

88. Jenkins G: The role of proteases in transforming growth factor-beta activation. Int J Biochem Cell Biol 2008, 40:1068-1078

89. Gopinathan A, Denicola GM, Frese KK, Cook N, Karreth FA, Mayerle J, Lerch MM, Reinheckel T, Tuveson DA: Cathepsin B promotes the progression of pancreatic ductal adenocarcinoma in mice. Gut 2012 , 61:877-884

90. Connolly EC, Freimuth J, Akhurst RJ: Complexities of TGF-beta targeted cancer therapy. Int J Biol Sci 2012, 8:964-978

91. Elie BT, Gocheva V, Shree T, Dalrymple SA, Holsinger LJ, Joyce JA: Identification and pre-clinical testing of a reversible cathepsin protease inhibitor reveals anti-tumor efficacy in a pancreatic cancer model. Biochimie 2010, 92:1618-1624

92. Widmer DS, Cheng PF, Eichhoff OM, Belloni BC, Zipser MC, Schlegel NC, Javelaud D, Mauviel A, Dummer R, Hoek KS: Systematic classification of melanoma cells by phenotype-specific gene expression mapping. Pigment Cell Melanoma Res 2012, 25:343-353 